\title{
8
}

\section{im

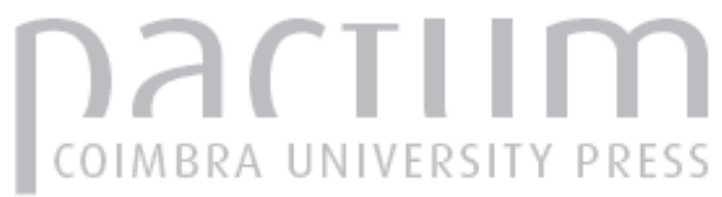

\section{Reading order and authenticity: the place of Theages and Cleitophon in platonic pedagogy}

\author{
Autor(es): $\quad$ Altman, William H. F.
}

Publicado por: Imprensa da Universidade de Coimbra

URL

persistente:

URI:http://hdl.handle.net/10316.2/42181

DOI:

DOI:https://doi.org/10.14195/2183-4105_11_2

Accessed : $\quad$ 26-Apr-2023 15:45:31

A navegação consulta e descarregamento dos títulos inseridos nas Bibliotecas Digitais UC Digitalis, UC Pombalina e UC Impactum, pressupõem a aceitação plena e sem reservas dos Termos e Condições de Uso destas Bibliotecas Digitais, disponíveis em https://digitalis.uc.pt/pt-pt/termos.

Conforme exposto nos referidos Termos e Condições de Uso, o descarregamento de títulos de acesso restrito requer uma licença válida de autorização devendo o utilizador aceder ao(s) documento(s) a partir de um endereço de IP da instituição detentora da supramencionada licença.

Ao utilizador é apenas permitido o descarregamento para uso pessoal, pelo que o emprego do(s) título(s) descarregado(s) para outro fim, designadamente comercial, carece de autorização do respetivo autor ou editor da obra.

Na medida em que todas as obras da UC Digitalis se encontram protegidas pelo Código do Direito de Autor e Direitos Conexos e demais legislação aplicável, toda a cópia, parcial ou total, deste documento, nos casos em que é legalmente admitida, deverá conter ou fazer-se acompanhar por este aviso.

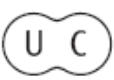




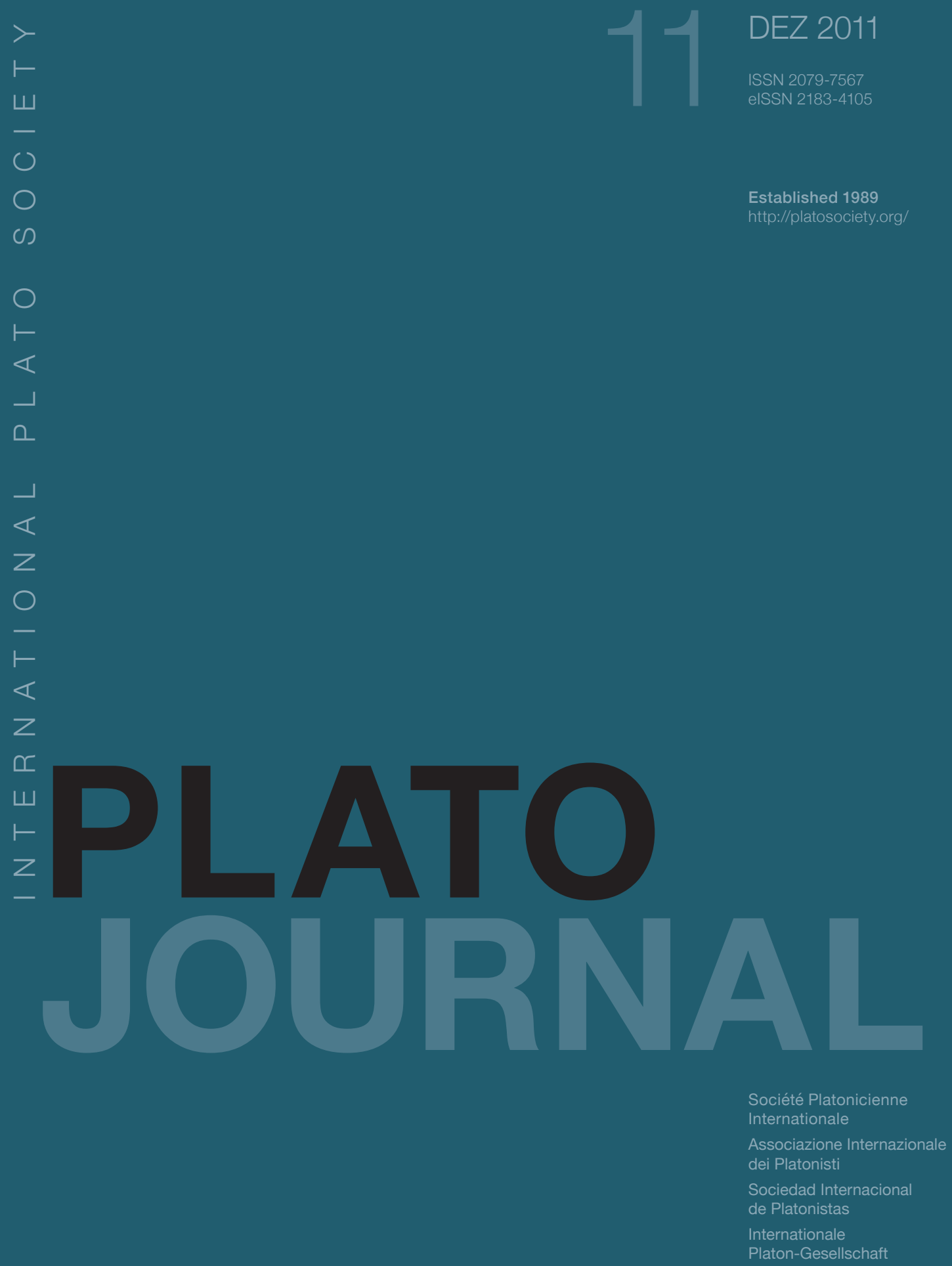




\title{
READING ORDER AND AUTHENTICITY: THE PlaCE OF THEAGES AND CLEITOPHON IN PLATONIC PEDAGOGY
}

\begin{abstract}
William H.F. Altman
The purpose of this paper is to show that a reconstruction of "the reading order of Plato's dialogues" 1 can be used as the basis for a new kind of argument for the authenticity of dubia like Theages and Cleitophon. ${ }^{2}$ Certainly the unwillingness of $21^{\text {st }}$ century scholars to trust dogmatic pronouncements about Plato's intentions-on the basis of which an earlier generation could assert that this or that dialogue was "un-Platonic" or "unworthy of Plato" (Grote 1865, 430)3 - has had the salutary effect of revitalizing the important question of how Plato, and thus how much of him, should be read. But despite the opening provided by this distrust where authenticity is concerned, I should emphasize from the start that a project based on reading order presupposes that Plato had discernable intentions, above all: the intention to teach and to teach well.
\end{abstract}

The comments of two anonymous readers have been very valuable.

${ }^{1}$ See Altman 2010a.

${ }^{2}$ I will apply the term dubia both to those dialogues among those recognized as authentic by Thrasyllus that have had defenders (the dubia proper; see Souihlé 1930) and those that, for the most part, have not, a classification by which a dialogue like Hipparchus would belong among the spuria not the dubia. I would restrict the term "spuria" to dialogues like Axiochus (Souihlé”s "dialogues apocryphes") about which I will have nothing to say here. Rowe 2007, 198-9 represents current opinion on the Platonic dubia. There is also some question as to the spelling of "Cleitophon" which I have hesitantly adopted, over the purist's reasonable objections, in preference to an overly radical transliteration Kleitophon and the equally consistent but otherwise unfortunate Clitophon.

${ }^{3}$ On Grote, an important nineteenth-century defender of Cleitophon, see Demetriou 1999. Leo Strauss's students have been in the vanguard of a twentieth-century re-appraisal of the dubia beginning with Pangle 1987 or rather Strauss 1964, 55; cf. Strauss to Alexander Kojève, 22 April 1957; Chicago, at Strauss 2000, 274-5: “As for your remark on Alc I (of course it is genuine, everything which has come down to us as genuine is genuine)...”

PLATO, The electronic Journal of the International Plato Society, n 11, 2011. http://gramata.univ-paris1.fr/Plato/article103.html

(c) All rights of reproduction of any form reserved. 
The time is ripe for this project in other respects. In Plato's Philosophers; The Coherence of the Dialogues (2009), Catherine Zuckert has used dramatic chronology to integrate all thirty-five dialogues accepted by Thrasyllus into a coherent narrative unfolding in time, thereby offering an exciting challenge to the dogma of "Plato's development." ${ }^{4}$ Unlike Zuckert's, however, the coherent interdialogue narrative under consideration here is pedagogical rather than strictly chronological: my emphasis will be on Plato as a teacher and I am interested in showing the pedagogical value of reading his dialogues in a certain order. By considering a series that includes both genuine dialogues and dubia, I will show how Theages and Cleitophon prepare the reader for Republic, thereby making it easier for the student to see the thematic interconnections between Gorgias, Theages, Meno, Cleitophon, and the Allegory of the Cave. It is on the pedagogical value of these thematic interconnections that my authenticity argument rests. But even a demonstration that these interconnections exist necessarily depends on a prior willingness to read the Platonic dubia in the first place and, here again, the time is ripe. Recent work on Theages (Bailly 2003a, Bailly 2004) ${ }^{5}$ and Cleitophon (Slings 1999, ${ }^{6}$ Bailly 2003b) has answered old arguments (most notably Heidel 1896) for athetizing them without advancing compelling new arguments for restoring them to the canon; this leaves room for the argument based on pedagogical coherence presented here.

In Section $\$ 1$, the reading order hypothesis will be used to show how Cleitophon prepares the reader for Republic and then, in Section $\$ 2$, how Theages does so. Section $\$ 3$ will then show how Theages bridges the gap between Gorgias and Meno. Having given the reader a sense of how the reading order hypothesis can be applied to questions of authenticity, Section $\$ 4$ will address a methodological circularity: only by reading Cleitophon and Theages as if they were

${ }^{4}$ For my review of Zuckert 2009, see Altman 2010c

5 Bailly 2004, 71: “Admitting that it [sc. Theages] is not as good as Plato's usually accepted works does not mean we have to deem it absolutely bad, nor that it is not by Plato. My conclusion to the authenticity question is that the dialogue should remain of "dubious" Platonic authorship, although it is undoubtedly genuine in other senses." Not only as the foil for Bailly but for many thoughtful observations, Joyal 2000 must also be cited.

6 Slings 1999, 233-4: "Therefore, although not without hesitation, I accept the Clitophon as a genuine work of Plato.” Demetriou 2000 is a thoughtful and indeed indispensable meditation on Slings.

PLATO, The electronic Journal of the International Plato Society, n 11, 2011.

http://gramata.univ-paris1.fr/Plato/article103.html

(c) All rights of reproduction of any form reserved. 
genuine can their place in the reading order be proved. While considering this variant on the hermeneutic circle, I will show how the reading order hypothesis resolves two problems in Platonic hermeneutics by employing the method associated with dialectic in the Divided Line. Finally, Section $\$ 5$ will summarize how Gorgias, Theages, Meno, Cleitophon, and Republic constitute a pedagogically coherent series within the reading order of Plato's dialogues.

\section{Section $\$ 1$. Cleitophon and Republic}

Considered in isolation, Cleitophon seems both incomplete and inauthentic. And this is the point: the reading order hypothesis means that no dialogue must be considered in isolation. It is not difficult to identify "unPlatonic" elements in a dialogue where Socrates is attacked and offers no defense to Cleitophon's extra-legal "charge." But Thrasyllus recognized that Cleitophon doesn't stand in isolation: his Eighth Tetralogy consists of Cleitophon, Republic, Timaeus and Critias. When Republic follows Cleitophon, as Zuckert (2009, 3325) too argues that it does, Socrates' lengthy monologue must be understood as his response to Cleitophon. In the context of reading order, then, Cleitophon should not only be recognized as the introduction to Republic (Souilhé 1949, 179) but as its literary provocation.

To begin with, then, there has been considerable discussion of "the riddle of the Cleitophon." While the only "riddle" for those scholars who athetize the dialogue involves discovering its author and determining that author's purpose, those who ascribe the dialogue to Plato must confront the riddle of "Socrates' Silence" in the face of "Cleitophon's Challenge." Based on the reading order hypothesis, my approach is to solve this "riddle" by reading Republic as Socrates' response to "Cleitophon's Challenge," i.e., I claim that "Socrates' Silence" is broken in Republic and therefore that Cleitophon, when read as an introduction

7 In addition to the eponymous Geffcken 1930 and Roochnik 1984, see Slings 1999, Demetriou 2000, and Bowe 2007.

${ }^{8}$ Orwin 1982, 751; Blits 1985, 321 and 334; Bruell 1999, 199; Kremer 2000, 494, Kremer 2004, 2; Saxonhouse 2005, and Plax 2006.

${ }^{9}$ Bailly 2003b, 111; Mishima 2010 and Benson (forthcoming); cf. Blits 1985, 321 and 330.

PLATO, The electronic Journal of the International Plato Society, n 11, 2011. http://gramata.univ-paris1.fr/Plato/article103.html

(c) All rights of reproduction of any form reserved. 
to it, can be proved to have a genuine place among the dialogues of Plato. But before defending my approach, it will be useful to situate it in the context of the recent revival of interest in "the riddle of the Cleitophon."

In reviewing the work of previous scholars, ${ }^{10}$ G.S. Bowe (2007, 249; cf. 245) has usefully distinguished three ways of considering Cleitophon en route to defending the third as his own: (1) as preceding Republic in a dramatic sense, (2) as following Republic, and (3) as independent of Republic. ${ }^{11}$ Despite Bowe's "In Defense of Clitophon," I do not believe that the dialogue will be welcomed back into the canon on the basis of a stand-alone approach alone; ${ }^{12}$ even if a new consensus pronounces it genuine, it would-much like Critias-probably be regarded as unfinished. Moreover, given the fact that two of the three approaches distinguished by Bowe situate it in proximity to Republic, it seems unnatural to divorce them, ${ }^{13}$ especially because the dogma of "hermeneutic isolationism"14 i.e. the claim that each of Plato's dialogues must be evaluated without reference to any other-is so easily refuted on the basis of dyads like Timaeus-Critias and Sophist-Statesman. ${ }^{15}$ Indeed it is the implicit application of this isolationist

${ }^{10}$ Bowe 2007 is no longer up to date nor does it address the prior Davis 1998 and Ausland 2005. For the best available bibliography, see Moore 2010.

${ }^{11}$ This scheme is preferable to the four-fold classification at Roochnik 1984, 134; his (emphasis mine) "(4) The dialogue is a self-contained Platonic work and worthy of serious study," although it comes closest, leaves no room for the approach I am proposing; although I do not regard Cleitophon as "self-contained," it is nevertheless "a...Platonic work and worthy of serious study.” For Roochnik's position, see 138.

${ }^{12}$ Ficino, A. E. Taylor, Paul Shorey, and S. R. Slings are cited at Bowe 2007, 248 as examples of scholars who changed their minds on the authenticity of Cleitophon; this illustrates how little certainty exists on the question.

${ }^{13}$ Saxonhouse 2005, 128: “...clearly a companion piece to the Republic.”

${ }^{14}$ E.g. Press 1993, 109-11.

${ }^{15}$ To say nothing of the Alcibiades and Hippias twins along with Laws-Epinomis. Bowe 2007, 253 n. 42 rejects the authority of Thrasyllus for reading Republic after Cleitophon (as well, presumably, for reading Timaeus after Republic and Critias after Timaeus) on the basis of the criticism of the tetralogical scheme found in Grote. Although I reject Thrasyllus' organization by tetralogies-the first ignores, for example the Sophist-Statesman dyad interpolated between Euthyphro and Apology, and his decisions to split some dyads (e.g. Hipparchus and Minos) while creating others (e.g. Symposium and Phaedrus) - Thrasyllus gets the Eighth Tetralogy right if only by recognizing its three dyads.

PLATO, The electronic Journal of the International Plato Society, n 11, 2011. http://gramata.univ-paris1.fr/Plato/article103.html

(c) All rights of reproduction of any form reserved. 
hermeneutic that makes the riddle of "Socrates' Silence" particularly difficult and pressing.

But "Socrates' Silence" in the face of "Cleitophon's Challenge" is likewise more difficult for those who favor (2) over (1): if "Cleitophon's Challenge" is not answered in Republic, then an explanation for "Socrates' Silence" must be found elsewhere, i.e. in some extra-textual — and thus even less likely-place. In addition to following the ancient indication provided by Thrasyllus, ${ }^{16}$ (1) has the advantage that it eliminates the problem of "Socrates' Silence" at the start: Socrates is not silent. But because "Cleitophon's Challenge" is formidable, Socrates will require the entire Republic to meet it just as he will require nine more books to meet the challenge offered by Glaucon and Adeimantus at the beginning of Republic II.

In arguing for (3), Bowe advances arguments against both (1) and (2). Although his argument against (2) might be supplemented, ${ }^{17}$ it is his argument against (1) that is relevant here: ${ }^{18}$

Those who take the dialogue as complete and authentic often place the Clitophon dramatically before the Republic. While

${ }^{16}$ For the arrangement of Thrasyllus as a reading order, see Dunn 1976 and Tarrant 1993, 179; cf. Cooper and Hutchinson 1997, x: “Thrasyllus' order appears to be determined by no single criterion but by several sometimes conflicting ones, though his arrangement may represent some more or less unified idea about the order in which the dialogues should be read and taught."

${ }^{17}$ Particularly with respect to the absent Davis 1998; cf. Altman 2012, 32-3 n. 98.

18 The objection to (1) on the basis of "comfort" developed in Bruell 1999, 189-99 (especially 192-3 and 197) is particularly revealing but requires separate treatment; see Strauss 1989, 41 and Altman 2011, 102-3, 111 n. 184-112, 250, 350 n. 5, and 444. For a friendlier critique, see Kremer 2000, 492 n. 20 and 500 n. 28. Incidentally, it is thanks to the lack of any clear guidance from Strauss himself about Cleitophon that this quarrel between two able Straussians becomes possible; cf. Saxonhouse 2005, 129 on the common ground between Orwin 1982, Roochnik 1984 ("powerful and scary" at Saxonhouse 2005, 131), and Blits 1984. The question of "comfort" is also implicit in Blits 1984, 334 ("one of Socrates' failures") and Kremer 2004, ix: it was Nietzsche's critique of Plato that led him to Cleitophon and he "was unable to discover" in it (emphasis mine) "a Socrates worthy to be Nietzsche's antagonist and even critic." It will be noted that even the defense of (1) in Roochnik 1985 offers no "comfort."

PLATO, The electronic Journal of the International Plato Society, n 11, 2011.

http://gramata.univ-paris1.fr/Plato/article103.html

(c) All rights of reproduction of any form reserved. 
this may seem to some to be a more natural order, it also leads to interpretations of the Clitophon that see Clitophon as going from bad to worse, based on a few remarks in Republic $1 .{ }^{19}$

Bowe's argument depends on the assumption that Plato crafted Socrates' account of Cleitophon in Republic I in accordance with historical verisimilitude broadly construed: ${ }^{20}$ once the great monologue he delivers is recognized as Socrates' immediate response to "Cleitophon's Challenge," ${ }^{21}$ Bowe's central objection to (1) becomes irrelevant. ${ }^{22}$ It is my hope that parental storytellers will immediately recognize from experience the efficacy of inserting their own child in the midst of a cautionary tale. The "radical relativist" whom Socrates calls "Cleitophon" in Republic I is who Cleitophon may well become if he fails to recognize that Socrates' response to his challenge in Republic VI and VII-beginning with the Idea of the Good-constitutes Plato's refutation of relativism. ${ }^{23}$

${ }^{19}$ Bowe 2007, 251; cf. the somewhat stronger statement at 249: "Those who take the dialogue as complete and authentic place the Clitophon dramatically ahead of the Republic." See Kremer 2000 for emphasis on the "movement" that Bowe calls "going from bad to worse."

${ }^{20}$ Cf. Orwin 1982, 752: “As has been argued above, we need not take this ending to imply that Kleitophon has left Socrates speechless. It means merely that Socrates' reply is somehow beside the point, which fact requires interpretation. We learn from the Republic, however, that Kleitophon continues to frequent Thrasymachus: whatever Socrates may have replied, it did not satisfy him." Comparable is Ausland 2005, 416: “He [sc. Cleitophon] thinks I'm [Ausland is imagining what Socrates might have said to himself] unwilling to give him more but I know I'm unable [cf. Rutherford 1995, 100 and Bailly 2003, 116]. Yet he also seems elated by his own rhetorical performance, so I had best not say anything just now. Perhaps I'll take the next opportunity that arises to converse in front of him with Thrasymachus and try to get beyond our usual quarrel."

${ }^{21}$ Bowe 2007, 245 n. 3 (emphases mine): "I do not mean to imply (in the case of Republic 1 and Clitophon) that we should think of this [sc. 'dramatic ordering'] as an uninterrupted dramatic order, although it is possible to do so on some accounts." I am implying this but Bowe does not address any other accounts that do so.

22 Bowe 2007, 257: “The assumption that the Clitophon comes before Republic 1 and that this must mean that we are to understand that Clitophon has followed through on his threat to join forces with Thrasymachus requires us to accept $\mathrm{A}^{2}$ over ADF and places the weight of interpretation on Republic 1."

23 "Radical relativism" is the felicitous phrase introduced at Roochnik 1985, 140. Not so felicitous is his claim on 141 that "in neither of the two dialogues is Cleitophon refuted by

PLATO, The electronic Journal of the International Plato Society, n 11, 2011.

http://gramata.univ-paris1.fr/Plato/article103.html

(c) All rights of reproduction of any form reserved. 
In the context of Platonic pedagogy, however, I should qualify my statement that Cleitophon is followed immediately by Plato's Republic: it would be a mistake to fall once again into the happy confusion of Hippolytus the Christian, who regarded the two dialogues as one (Bowe 2007, 246). Once the dialogues are recognized as teaching tools and the reading order is recognized as a coherent syllabus, one has already begun to ask: "How would Plato have taught his dialogues in the Academy?" One thing is certain: if Cleitophon is genuine, he separated it from Republic. I therefore do not believe that Plato expected anyone to read or hear the one immediately after hearing or reading the other. Given the practice of all good teachers, especially those influenced by Plato, it is natural to assume that some discussion followed an encounter with Cleitophon. I therefore suspect the first academicians were asked: "What do you think Socrates replied to Cleitophon?” before learning from Plato's Republic how he did.

Abandoning this speculative Academy for more modern concerns, I am claiming that Cleitophon is the first-order audience for Socrates in Plato's Republic. ${ }^{24}$ Socrates thereby breaks his silence in order to respond to "Cleitophon's Challenge," attempts to warn him off from Thrasymachus, and even preemptively attacks the "radical relativism" or "legal positivism" that Socrates' Cleitophon defends in Republic I. ${ }^{25}$ To put the central point yet another way: I am claiming that the Cleitophon who appears in direct dialogue in Cleitophon is the Cleitophon whose "challenge" provokes the reply Socrates

Socrates." Roochnik grounds his decisionist "defense" of philosophy (cf. "judgment" at 142 with "faith" at Strauss 1997, 131) on the following false claim (141): "Philosophy depends upon an unconditional affirmation of the goodness of philosophical discourse, a value which for it is axiomatic." As presented in Republic VI-VII, the Socratic philosopher recognizes only the unconditional goodness of the Idea of the Good (533b8-d1); the goodness of the discourse that ascends to it is hypothetical, not axiomatic $(511 \mathrm{~b} 2-6)$.

${ }^{24}$ Plato's readers are his second-order audience; the rest of the fictional audience in the home of Polemarchus could perhaps be reckoned his third-order audience.

25 Bowe 2007, 253: "If we accept that Roochnik's "relativism" or Orwin's "legal positivism" deserves no good response, we are left wondering why the Republic provides such a good response to it - why it provides a reason for believing that justice is higher than law and thus is not a matter of mere convention-or, as one might more traditionally say, why the Republic

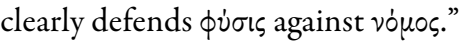

PLATO, The electronic Journal of the International Plato Society, n 11, 2011. http://gramata.univ-paris1.fr/Plato/article103.html

(c) All rights of reproduction of any form reserved. 
makes in Republic whereas the Cleitophon whose words and actions Socrates narrates there is a counter-factual "Cleitophon," constructed by Socrates for a pedagogical purpose, ${ }^{26}$ one who has, under Thrasymachus' influence, already made the move "from bad to worse."

If reading Republic as Socrates' immediate response to "Cleitophon's Challenge" disposes of Bowe's objection to (2), his defense of (3) actually strengthens my case. This defense rests on separating an "aporetic" Socrates from a "constructive" Socrates-an approach that necessarily involves considering Cleitophon in the context of other dialogues, especially Republic-and reading Cleitophon as a respectful critique of "the aporetic Socrates":

For if the Socrates that Clitophon is criticizing in the Clitophon is the aporetic Socrates and not the constructive one, the reason for his silence is obvious-his work with Clitophon in this frame of mind and at this stage of development is over. ${ }^{27}$

This is likewise the way I read Cleitophon: its protagonist forces Socrates to break the kind of "silence" 28 that characterizes the Socrates of the aporetic dialogues and thus to offer a constructive answer to "Cleitophon's Challenge." Given the totality of the Platonic dialogues, and particularly given his Republic, Bowe shows why Cleitophon's principal claim is false (Bowe 2007, 263): "Socrates is only an impediment if one mistakes the aporetic Socrates for the constructive one." In the same way, the post-Thrasymachean Cleitophon depicted by Socrates in Republic I is only an impediment to recognizing Cleitophon as an introduction to Republic if one mistakes the constructive Socrates of Plato's Republic for the aporetic one

${ }^{26}$ Socrates does something similar to Ctesippus in Euthydemus; see Altman 2007.

${ }^{27}$ Bowe 2007, 261; cf. 259: “The idea that Clitophon's claims may make sense as a response to Republic 1, which is aporetic in form, but not to Republic 2-10 suggests that Clitophon is directing his remarks at the Socrates of the aporetic dialogues." Just as the real Cleitophon confronts the aporetic Socrates, the constructive Socrates constructs a counter-factual Cleitophon.

${ }^{28}$ Bowe 2007, 263: "Socrates' silence at the end of the Clitophon, then, is best explained by the fact that the aporetic Socrates can do no more for Clitophon."

PLATO, The electronic Journal of the International Plato Society, n 11, 2011.

http://gramata.univ-paris1.fr/Plato/article103.html

(c) All rights of reproduction of any form reserved. 
and insists that Plato valued historical verisimilitude more highly than pedagogical effectiveness.

To turn to the dialogue itself: Cleitophon is willing to admit that the speeches of Socrates are "...most valuable admonitions and most useful

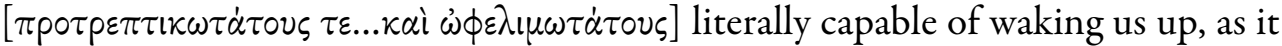
were, out of our slumber." ${ }^{29}$ But he wants "to hear what was to follow next." The phrase $\tau \grave{o} \mu \varepsilon \tau \dot{\alpha} \tau \alpha \tilde{\nu} \tau \alpha$ ("that which comes after these things;" translation mine) is the Leitmotiv of the Cleitophon (408c4, 408c9, and 408d7) and this makes sense once we realize that it is Republic that will do so. Now that he has been persuaded to seek virtue, Cleitophon wants to know how to practice it; he is therefore "...inquiring what discourse might be the one after these $[\pi \nu v \theta \alpha \nu \dot{\alpha} \mu \varepsilon v o s \tau i \varsigma \delta$ o $\mu \varepsilon \tau \dot{\alpha}$

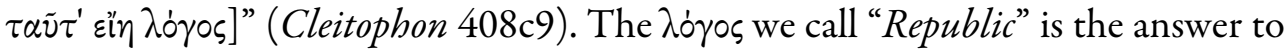
this question.

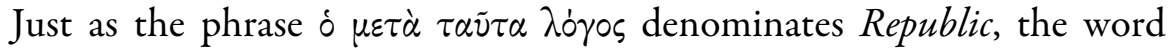
" $\tau \alpha \tilde{\tau} \tau \alpha$ " refers here to the aporetic dialogues the reader has already read before reading Cleitophon. At this point in his well-ordered pedagogical program, ${ }^{30}$ Plato employs Cleitophon to represent what any critical student/reader of the foregoing series of primarily aporetic/elenctic dialogues would understandably be feeling/seeking before reading/hearing Republic. In Cleitophon, then, Cleitophon is asking for Republic: begging for it, as it were:

"I ask you, my very good Sirs, in what sense do we now accept the exhortation to virtue which Socrates has given us. Are we to regard it as all there is, and suppose it to be impossible to pursue the object [sc. virtue] further and grasp it fully

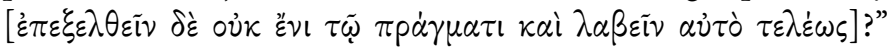
(Cleitophon 408d1-4; cf. Slings 1999, 302)

${ }^{29}$ Cleitophon 408c2-4; unless noted, all translations from this dialogue are by Francisco Gonzalez in Cooper and Hutchinson 1997. All references to Plato are based on Burnet 19001907 except those to Republic, which are based on Slings 2003 and are cited by Stephanus number alone.

${ }^{30}$ See Altman 2010a, 44.

PLATO, The electronic Journal of the International Plato Society, n 11, 2011. http://gramata.univ-paris1.fr/Plato/article103.html

(c) All rights of reproduction of any form reserved. 
From what Cleitophon (or any given student) can glean from the early dialogues-i.e. "early" with respect to reading order-it does not seem that he can either "grasp virtue fully" or put these lessons into practice $(\tau \tilde{\omega} \pi \rho \dot{\alpha} \gamma \mu \alpha \tau \iota)$. As Plato's paradigm for the committed student, Cleitophon not only wants to know what comes next, he wants to know what to do next. In lieu of answers, he sees only a disappointing alternative:

....and is this to be our lifelong task, just to exhort those who have not as yet been exhorted, and that they in turn should

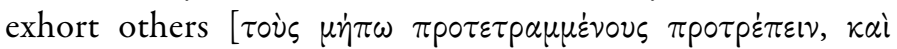

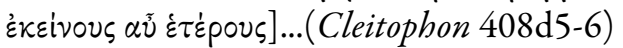

Is this all Socrates can offer his hearers (or Plato his readers): that they exhort others to leave behind false virtues and search for real ones?

Or, when we have agreed that this is exactly what a man

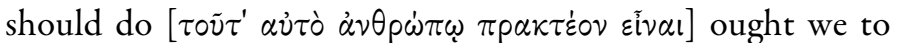
ask Socrates, and one another, the further question [ $\tau \dot{0} \mu \varepsilon \tau \dot{\alpha}$

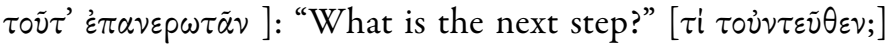
(Cleitophon 408d7-e2)

This is the crucial passage in Cleitophon, hereafter to be called "Cleitophon's question," an alternative to the conventional but overly polemical "Cleitophon's Challenge." It is a practical question, most effectively distilled into

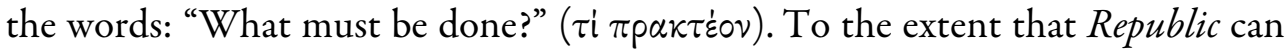
easily be read, and has repeatedly been read since antiquity (Stahl 1990, 81), as a purely theoretical work - as Plato's program for an ideal city-its proximity to Cleitophon constitutes the best extra-textual reason for reading it differently. In this way, the reading order hypothesis allows a lesser dialogue like Cleitophon to play a significant if not necessary part in elucidating the far more important dialogue that follows it.

Naturally this is not the proper place to offer an interpretation of Plato's Republic that will justify reading it as a response to Cleitophon's question. In another place, ${ }^{31}$ I develop this interpretation in detail. But the heart of this

${ }^{31}$ Altman 2012

PLATO, The electronic Journal of the International Plato Society, n 11, 2011. http://gramata.univ-paris1.fr/Plato/article103.html

(c) All rights of reproduction of any form reserved. 
interpretation is the contrast between the Longer Way that Socrates first mentions in Book IV (435d2-3) and the methods that lead, in that same book, to definitions of justice in the City and the Man. I interpret this contrast in the context of the Divided Line and argue that the methods used by Socrates in Book IV, like those of the second $(511 \mathrm{e} 1)$ or mathematical segment of the Divided Line (510c2d-3), depend on unquestioned hypotheses and the use of images (510b4-8). More pertinent in the current context is the claim that Plato has

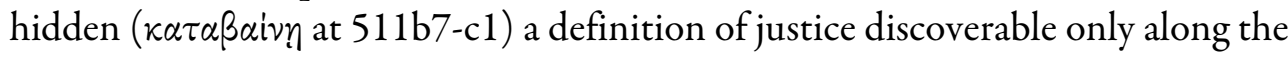
Longer Way (cf. 504b1-505a4 and 511b2-c2)-one that both depends on the Idea of the Good and at the same time answers Cleitophon's question (cf. Grube 1931, 303) - amidst the shadows of the Cave. ${ }^{32}$

In the present case, Cleitophon's question will eventually receive its

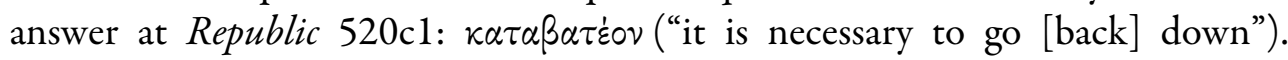
When Plato's Republic is read as Socrates' answer to Cleitophon's question, it becomes much easier to recognize that the obligatory $\kappa \alpha \tau \alpha \beta \alpha \tau \varepsilon$ ' important by Socrates' opening word ( $\kappa \alpha \tau \dot{\varepsilon} \beta \eta \nu$ at $327 \mathrm{a} 1$ ), is addressed not only to the temporarily captious Guardians (520a7) as represented by their skilful

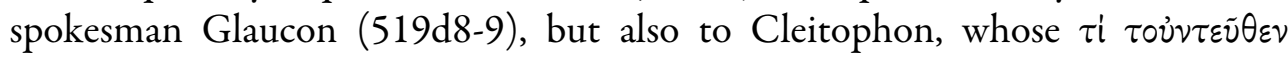
provokes it. And once the narrative frame has been broken by our awareness of Cleitophon's semi-textual presence as Socrates' first-order audience, Plato has opened the door to applying $\kappa \alpha \tau \alpha \beta \alpha \tau \dot{\varepsilon} \circ \nu$ both to Glaucon (Yunis 2007; cf. $520 \mathrm{e} 1)$ and, most importantly, to us. ${ }^{33}$

To repeat the crucial point: I read this verbal adjective as an obligation not only imposed upon the momentarily rebellious Guardians by Socrates qua

32 An invaluable question is posed at Burnyeat 2000, 46: "They return [sc. the philosophers to the Cave] having seen 'justice itself (517e [517d10-e1 in Slings]). But when?" On my account, the fact that they have voluntarily returned to the Cave (compulsion enters only at 519c8-d7) ipso facto means that they have acted upon and have therefore seen "justice itself."

${ }^{33}$ A willingness to see themselves addressed by Socrates' "you" ( $(\mu \tilde{\alpha} s)$ at 520 b5 creates in Plato's receptive readers what I call "the crisis of the Republic" (Altman 2012); the Shorter Way, by contrast, would specifically exempt the typical reader from any such obligation and confine "you" to the hypothetical Guardians of an imaginary City. I call the Guardians "hypothetical" because their "existence" follows from the hypothesis on which the imagined city depends; cf. $370 \mathrm{a} 4$ and 374a5-6.

PLATO, The electronic Journal of the International Plato Society, n 11, 2011. http://gramata.univ-paris1.fr/Plato/article103.html

(c) All rights of reproduction of any form reserved. 
founder of an imaginary city-this is merely the word's literal context in accordance with the Shorter $\mathrm{Way}^{34}$-but dialogically directed at Plato's perceptive auditors whether among those I have called his first-, second, or thirdorder audiences. When guided to Plato's Socratic answer by Cleitophon's question, $\tau \dot{o} \mu \varepsilon \tau \dot{\alpha} \tau \alpha \tilde{v} \tau \alpha$ tells any given "Cleitophon" precisely what comes next and, above all, where to go from here: ${ }^{35}$ back down into the Cave of political life. ${ }^{36}$ In short: Cleitophon's "What is the next step?" $(\tau i \text { } \tau 0 \nu \nu \tau \varepsilon \tilde{v} \theta \varepsilon v ;)^{37}$ receives its answer in that immortal $\lambda$ óyos whose first word is $\kappa \alpha \tau \dot{\varepsilon} \beta \eta \nu$. It should also be emphasized that the description of the just man in Republic IV leaves it unclear whether he/she will actually do much of anything; ${ }^{38}$ the City that requires the philosopher to return to the Cave brings to light a justice that explains exactly

${ }^{34}$ Leading as well to the much-debated problem of the philosopher's motivation for ruling; for a recent treatment of "this celebrated crux," see Sedley 2007, 276-81 and Ferrari 2007, 497-8, a useful bibliography on the question of the philosopher's willing return to the Cave. In Altman 2009a, I have shown why it is impossible to reconcile the philosopher's altruistic decision to return to the Cave with justice as defined in Book IV and thus why so many have attempted without success to reconcile them.

${ }^{35}$ While Rowe 2007, 55-65 emphasizes the Cave for gaining an adequate understanding of Plato, the return to it is mentioned only in a summary ( $55 \mathrm{n.}$ ).

${ }^{36}$ Cicero is the best example of a Platonist who returned to the Cave (Altman 2009a and 2009b] and it is significant that he (and many other ancient authorities) regarded Demosthenes as Plato's auditor (Douglas 1966, 100).

${ }^{37}$ Although $\dot{\varepsilon} \tau \varepsilon \tilde{\nu} \theta \varepsilon \nu$ ("thence") is common, when combined with the definite article $(\tau i$ $\tau \circ \mathcal{\nu} \nu \tau \varepsilon \tilde{\nu} \theta \varepsilon \nu$ ), it is comparatively rare; cf. Theaetetus $197 \mathrm{e} 1$ and Crito $49 \mathrm{~d} 6$. For its connection with

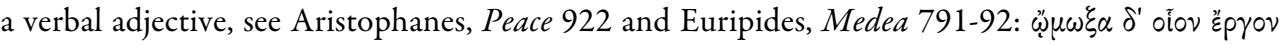

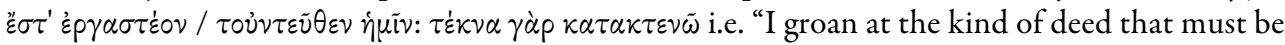
done / that's next for me: for my children I will kill" (translation mine). The verbal adjective

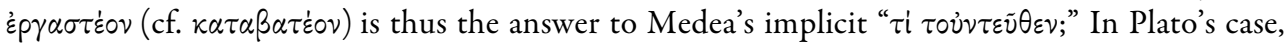
what's next to come is a dialogue where Socrates must save his children from the beastly Thrasymachus (336b5). Medea is first called a lion at Medea 1342 and then acknowledges its application to her at 1358, a lion that may live in a cave (gloss on 1359). In a further link with

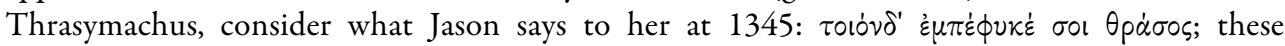
suggestions follow the lead of Nightingale 1995, 67-87.

${ }^{38}$ Note the emphasis (without commitment; see 443e3) on $\pi \rho \dot{\alpha} \tau \tau \varepsilon เ \nu$ and $\pi \rho \tilde{a} \xi ı$ at $443 \mathrm{c} 9-444 \mathrm{a} 2$; these words are used six times in this brief passage.

PLATO, The electronic Journal of the International Plato Society, n 11, 2011.

http://gramata.univ-paris1.fr/Plato/article103.html

(c) All rights of reproduction of any form reserved. 


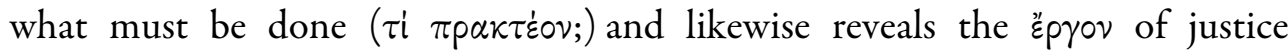
desiderated by Cleitophon. ${ }^{39}$

An authentic Cleitophon therefore supports the view that the purpose of Republic is not primarily to describe an ideal city but to illuminate justice (472b35). Justice will be illuminated by Socrates so that Cleitophon and Glaucon-and, by entering into a dialogic relationship with the text, the reader as well-will be challenged to practice it: the torch of justice blazes (Republic 435a1-2) so that it may be passed along (328a3-4) but it is only by returning to the City that it can be kindled (434e5). The stakes are remarkably high and Plato uses both parts of the Cleitophon-Republic dyad to illustrate this: although Socrates answers Cleitophon's question only in Republic, the consequence of his failure to do so-a consequence that will be made palpable in Republic - is already made explicit in Cleitophon:

\begin{abstract}
...And someone might accuse you of being in the same position with justice, that your ability to praise it so well does not make you anymore knowledgeable about it [ov $\mu \tilde{\alpha} \lambda \lambda \circ \nu$

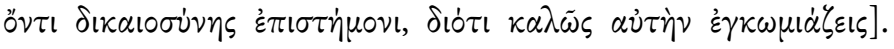
Now that's not my own view, but there are only two possibilities: either you don't know it, or you don't wish to share it with me. And this is why, I suppose, I go to Thrasymachus and to anyone else I can; I'm at a loss. ${ }^{40}$
\end{abstract}

Instead of allowing his Cleitophon to play the part of a good man (Republic 347c3-4)-i.e. the philosopher who prevents the ignorant and quarreling sailors (488b2-7) from administering mandragora to the noble but befuddled ship-owner (488c4-5; cf. 347c3-d2)-Socrates depicts him in the audience at the home of Polemarchus (328b4) offering Thrasymachus aid in a brief exchange (340a3-b8; cf. Kremer 2004, 26-7). As indicated above, the fact that Socrates represents Cleitophon in Republic as an ally of Thrasymachus tells us less about Cleitophon than about the pedagogical technique of Plato's Socrates. It is worth pointing out that Timaeus, which naturally follows Republic

${ }^{39}$ For the épyov of justice at Cleitophon 409b3-410a6, see in particular Roochnik 1984, 136-7. Cf. 519c8

${ }^{40}$ Cleitophon 410c2-c8; for the last sentence, see Bowe 2007, 254.

PLATO, The electronic Journal of the International Plato Society, n 11, 2011.

http://gramata.univ-paris1.fr/Plato/article103.html

(c) All rights of reproduction of any form reserved. 
in the reading order of Plato's dialogues, reveals that Socrates can tell the Republic "story" in different ways to different audiences (Timaeus 19b1-2). In any case, the remaining nine books of Republic give any given "Cleitophon" sufficient time and ample cause to change his or her position and, once having exited it (520e8521a2), to follow Socrates back down into the Cave. And this is what the historical Cleitophon, as Theramenes' ally, actually did. ${ }^{41}$

Leaving the controversies of Athenian politics aside, there is still a specifically Platonic problem: if this is what Plato's Socrates preaches, it is hardly obvious that he practices it (Hans 2006, 69). Just as Ion makes the boast that he could be a general (Ion 540d1-6), Socrates may well claim in Gorgias that he (alone) has what it takes to be an excellent politician:

I think that I am one of the few Athenians, not to say the only one, engaged in the true political art, and that of the men today, I alone practice statesmanship $[\pi \rho \dot{\alpha} \tau \tau \varepsilon l \nu \tau \dot{\alpha}$ $\pi \circ \lambda ı \tau ı \grave{\alpha}]$. (Gorgias 521d6-8; W.H. Woodhead translation)

But if Republic answers Cleitophon's question in the eminently practical manner sketched above, the question inevitably becomes a burning one: "Why didn't Socrates practice politics himself?"

\section{Section §2. Theages and Republic}

Socrates addresses this question twice, the first time-for most of us, that is ${ }^{42}$-is in Apology of Socrates (31c7-d6). Here he tells us that: (1) his divine Sign

${ }^{41}$ For Cleitophon's subsequent political career, see Nails 2002, 102-3, Raaflaub 1992, 37-8 n. 105, and Aristotle, Constitution of Athens, 29.2-3 and 34.3. Theramenes is little less controversial than Cicero as a politician due to his ongoing attempt to strike a reasonable and moderate balance between the few and the many; cf. Thucydides 8.97.2. On the second passage

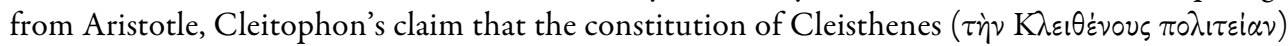
was not really $\delta \eta \mu о \tau \iota k \eta \dot{~ w a s ~ a n ~ a t t e m p t ~ t o ~ r e i g n ~ i n ~ t h e ~ e x t r e m e ~ o l i g a r c h s . ~}$

${ }^{42}$ It is worth pointing out that even those unwilling to entertain the reading order hypothesis have necessarily read whatever dialogues they have read in "a reading order"; i.e. there already exist as many de facto reading orders as there are readers of Plato. The Euthyphro, Apology, $C r i t o$, and Phaedo are among those dialogues that nearly everyone who has read Plato has read: i.e. they are very near the beginning of a de facto reading order, implicitly defended at Rowe 2007.

PLATO, The electronic Journal of the International Plato Society, n 11, 2011. http://gramata.univ-paris1.fr/Plato/article103.html

(c) All rights of reproduction of any form reserved. 
is purely negative and only prevents him from doing something he intended to do (31d3-4) and (2) the Sign prevented him from entering politics (31d5). In other words, by combining "(1)" and "(2)," we must learn for ourselves an important truth that is not made fully explicit in either of them: (3) that Socrates wished to enter, and was indeed on the verge of entering politics but was prevented from doing so by the Sign (Brickhouse and Smith 2000, 83-4). This is a crucial point for the interpretation of Republic that emerges in the context of Cleitophon: only if Socrates himself, having exited the Cave, willingly chose to practice politics ( $\pi p \dot{\alpha} \tau \tau \varepsilon \imath \nu \tau \dot{\alpha} \pi 0 \lambda \imath \tau \iota \dot{\alpha})$ can he consistently exhort us to do so. But Apology is not the only or perhaps even the first time that Plato's readers have been told about Socrates' blocked attempt.

The other time Plato tells us these same things is through a reader-made synthesis, identical to "(3)" in this respect, of two passages from two different dialogues: Republic and Theages. Theages is mentioned only twice in Platonic dialogues other than Theages: in Apology it is implied that he is dead (33e7) and in Republic that he is sickly (496c2). In Republic, Socrates is discussing the corruption of the philosophical nature and explaining that "the most capable" are prematurely-i.e., before having exited the Cave-diverted from philosophy into political life (496a11-b7). Socrates tells Adeimantus that Theages is one of the few who withstood this diversion. ${ }^{43}$ This, then, is the noteworthy passage where

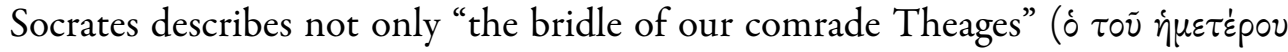

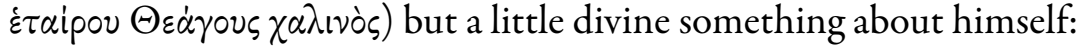

For in the case of Theages all other conditions were at hand for his backsliding from philosophy, but his sickly habit of body keeping him out of politics holds him back $[\dot{\alpha} \pi \varepsilon i p \gamma o v \sigma \alpha$

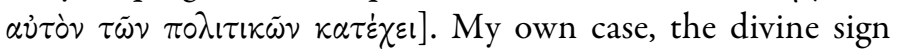

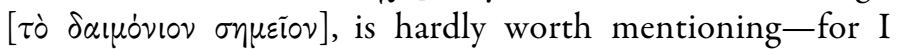
suppose it has happened to few or none before me. ${ }^{44}$

${ }^{43}$ Briefly discussed at Bailly 2004, 48, Joyal 2000, 59, and, most suggestively perhaps, Souilhé 1949, 138 (translation mine): "It is not impossible that reading this passage [sc. 496a11b7] and the connection [rapprochement] between the example of Theages and the example of the daimonion has furnished our dialogue-writer with a theme to develop." This seems considerably less likely than the solution proposed here but at least addresses the curious rapprochement.

44 496b7-c5; translations from Republic will be those of Paul Shorey.

PLATO, The electronic Journal of the International Plato Society, n 11, 2011. http://gramata.univ-paris1.fr/Plato/article103.html

(c) All rights of reproduction of any form reserved. 
Given that only in Theages could a reader who had not yet read Apology learn of "(1)," the fact that Plato here mentions Theages (which would necessarily remind the reader who has read it of Theages) immediately before asserting "(2)," this passage-causing a mindful reader to derive "(3)" from the synthesis of "(1)" and "(2)" - should be considered as the kind of playful puzzle about serious subjects that only great teachers can create. Here is the relevant passage from the Theages:

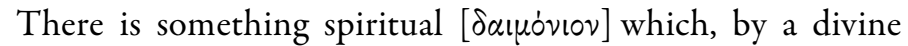
dispensation, has accompanied me from my childhood up. It is a voice that, when it occurs, always indicates to me a prohibition of something I may be about to do [0̈ $\ddot{\alpha} \nu \mu \dot{\varepsilon} \lambda \lambda \omega$ $\pi \rho \dot{\alpha} \tau \tau \varepsilon l \nu, \tau o \dot{\tau} \tau 0 \nu \dot{\alpha} \pi \circ \tau p \circ \pi \dot{\eta} \nu]$ but never urges me on to

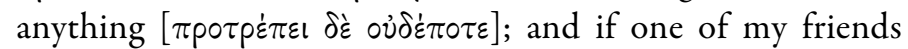
consults me and the voice occurs, the same thing happens: it prohibits, and does not allow him to act. ${ }^{45}$

It will be noticed that Theages contains a clear statement of "(1)" but no hint of "(2)." It should also be emphasized that there is no indication in Theages of what we learn only in Republic: that Theages is sickly with respect to body. In fact, it is quite entertaining to return to Theages with this passage in mind: imagining a very bright Theages afflicted with e.g. muscular dystrophy (496c2

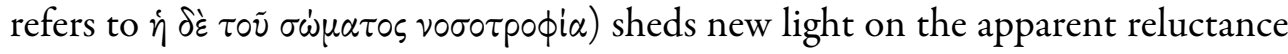
of Socrates to undertake his political education. It is certainly difficult to imagine that a forger would repress the only genuine fact about the living Theages while constructing a fraud that results in such a cleverly interwoven allusion about so crucial a subject. More importantly, without having read Theages, the juxtaposition of the Sign with Theages' physical disability in Republic VI is a non sequitur for the reader who is not aware of "(1)" and therefore cannot deduce "(3)." Only if we assume that Theages is mentioned in order to remind us of Theages does the passage in Republic VI become perfectly clear for the reader who hasn't read Apology. Not only does the apparent non sequitur vanish but the juxtaposition of two passages from two different dialogues forces readers to begin discovering for themselves-through recollection, as it were-something implicit in the first word of Republic: that Socrates could meaningfully say " $\alpha \alpha \tau \dot{\varepsilon} \beta \eta \nu$ " "I went down"). In short, the merely protreptic mission—of whose infinite regress

${ }^{45}$ Theages $128 \mathrm{~d} 2-5$; translations from Theages will be those of Nicholas Smith.

PLATO, The electronic Journal of the International Plato Society, n 11, 2011.

http://gramata.univ-paris1.fr/Plato/article103.html

(c) All rights of reproduction of any form reserved. 
Cleitophon (justly) complains - was not, it turns out, the first choice of Socrates, blocked as it was by the Sign: $\pi \rho \dot{\alpha} \tau \tau \varepsilon ı \nu \tau \dot{\alpha} \pi 0 \lambda ı \tau \iota k \dot{\alpha}$ is the course of action he intended for himself and for those of us who intend to prove ourselves just (520e1); this is Socrates' answer to Cleitophon's question.

If there is a reading order of Plato's dialogues, then, the pertinent question is whether its creator intended the reader of Republic VI to have already read (a) both Apology and Theages, (b) neither Theages nor Apology, (c) Apology but not Theages, or (d) Theages but not Apology. An exploration of these alternatives is intended to strengthen the hypothesis that there is a reading order, validate my reconstruction of this portion of it, and thereby advance a new kind of argument for the authenticity of Theages.

Any reader who admits the importance of “(3)" will see that "(b)" can be safely excluded because-given the absence of "(1)" in Republic - the reader could not derive "(3)" from it alone. If this line of argument is admitted, the reading order hypothesis may be said to have been thereby confirmed: Plato wanted the reader of Republic to know that Socrates intended to "go back down into the Cave" in a unequivocally political sense, even if Socrates, in accordance with Athenian usage, will call this "going up to the majority" at Apology 31c6. If the Theages is spurious, then, our only remaining choice is "(c)." But if the Theages is genuine, there are two more possibilities: "(a)" and "(d)." Of these, "(a)" seems uneconomical because it is only by combining old information from Theages with new information from Republic VI that Theages generates "(3)" in the first place. And if the reader has already read Apology, there is a double redundancy: the reader already knows that there is no need to discover the synthesis upon encountering "(2)" in Republic while remembering "(1)" from Theages because they have already encountered both of them in Apology. ${ }^{46}$ If Theages is genuine,

${ }^{46}$ It is perhaps for this reason that Friedrich Schlegel-who initiated the translation project that led to Schleiermacher's momentous Platons Werke (see Demetriou 2000, 133 n. 2) rejected the Apology as spurious but pronounced the Theages genuine. Lamm 2000, 213: “A second turning point [sc. in the troubled relations between Schleiermacher and Fr. Schlegel] occurred in December 1800, when Schlegel finally came through with his "Complexus of Hypotheses," in which he offered a brief chronology of Plato's dialogues (divided according to the three periods of Plato's career) and an even briefer explanation of his fundamental principles. Taking the concept of irony as his guiding principle, he arrived at the unusual conclusion that the Theages is authentic and the Apology inauthentic."

PLATO, The electronic Journal of the International Plato Society, n 11, 2011. http://gramata.univ-paris1.fr/Plato/article103.html

(c) All rights of reproduction of any form reserved. 
"(d)" is preferable to "(a)" because "(a)" is uneconomical and sidesteps the synthetic thought-process demanded by "(d)." That leaves only "(c)" and "(d):" the old dilemma. But now there is a new twist: if the "the Reading Order of Plato's Dialogues" actually exists, the best answer will be "(d)." To put it another way: if Theages is genuine, the reading order hypothesis has been confirmed.

A proof of the authenticity of Theages based on reading order therefore requires that it precedes-and Apology follows-Republic in reading order as it does on strictly chronological grounds for Zuckert. A backwards pointing allusion to Theages at Republic $496 \mathrm{~b} 7$ coupled with a prophetic prediction of the fate of Socrates both explains the mention of Theages at 496b7-8 and also justifies the order in which Plato has actually constructed the speech of Socrates at 496a11-e2. The self-portrait with which the speech in Book VI concludes prophetically describes the dangers that would befall "the champion of justice" who did enter politics:

...there is nothing, if I may say so, sound or right in any present politics, and that there is no ally with whose aid the champion of justice could escape destruction, but that he would be as a man who has fallen among wild beasts, unwilling to share their misdeeds and unable to hold out singly against the savagery of all... $\quad(496 \mathrm{c} 7-\mathrm{d} 5)$

In the context of reading order, the speech at 496a11-e2 looks both forward and back: backwards to Theages while foreshadowing Apology of Socrates.

Another observation about Platonic pedagogy is pertinent here: the connection between Theages and Republic, particularly as a catalyst for the readermade synthesis "(3)", suggests that Plato expected his students to apply the lessons of earlier dialogues to the interpretation of later ones. And thanks to the allusion to Theages in Republic VI, we can also see that Plato the teacher could be very generous in providing useful hints about how and when to do so. In short, the allusion to Theages in Republic VI gave Plato's students an opportunity to demonstrate the same kind of memory for which Socrates praises Glaucon at 544b3. But if Theages must be placed before Republic, it cannot stand immediately before it: Cleitophon already occupies that place. Where then in the reading order of Plato's dialogues does Theages belong?

PLATO, The electronic Journal of the International Plato Society, n 11, 2011.

http://gramata.univ-paris1.fr/Plato/article103.html

(c) All rights of reproduction of any form reserved. 


\section{Section \$3. Theages in relation to Gorgias and Meno}

Thrasyllus placed Theages first in the Fifth Tetralogy, preceding Charmides and Laches. This placement makes good sense because all three dialogues, as indicated by their traditional sub-titles, are devoted to a single virtue: Theages to wisdom, Charmides to temperance, and Laches to courage. But Thrasyllus gets the order wrong. For one thing, Laches is connected to Euthydemus in several ways and therefore follows $i t,{ }^{47}$ not Charmides. And as both W.K.C. Guthrie and R.K Sprague have been forthright enough to admit, ${ }^{48}$ Laches is an easier dialogue to understand than the admittedly similar Charmides; although this is not the place to prove it, ${ }^{49}$ this adds pedagogical priority to considerations of dramatic continuity. In any case, as indicated by "the bridle of Theages," dramatic details are essential clues for reconstructing the reading order of Plato's dialogues. ${ }^{50}$ For example: Theages refers to the two sons whose education is discussed in Laches (Theages 130a4-e4) as well as to "the beautiful Charmides" (Theages 128d8-e1) but it is clear that all three youngsters have already become companions of Socrates; in Laches (180a6) and Charmides (176b5), this companionship is proposed but does not yet exist. In other words, a consideration of dramatic allusion and sound pedagogical practice would suggest that the correct ordering of these slender dialogues should be Laches, Charmides, and Theages.

Unlike either Laches or Charmides, Theages refers to Gorgias and Polus (127e8-128a1), a reference suggesting that Theages also follows Gorgias. The statesmen Pericles, Cimon, and Themistocles are likewise used as negative examples in both Theages (126a9-10) and Gorgias (515d1). More importantly,

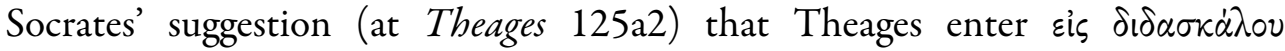

${ }^{47}$ Both dialogues take place in a gymnasium and "the man fighting in armor" (Laches 178a1) recall Euthydemus and his brother (Euthdemus 271d3).

${ }^{48}$ Sprague 1973, vii and Guthrie 1975, 125 and 163.

${ }^{49}$ See Altman 2010b.

50 This is a basic difference between my approach and Zuckert's: she relies on strictly chronological considerations to reconstruct reading order while I emphasize dramatic details tempered by chronological and pedagogical considerations. See Altman 2010b, 1-5.

PLATO, The electronic Journal of the International Plato Society, n 11, 2011.

http://gramata.univ-paris1.fr/Plato/article103.html

(c) All rights of reproduction of any form reserved. 


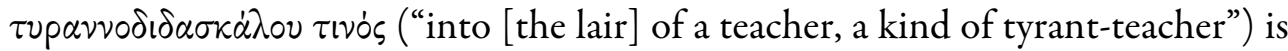
thematically connected with Gorgias: the question of Gorgias' responsibility qua teacher for the unjust actions of his students may be said to be one of that dialogue's principal themes (Gorgias 456e2-457e4). When Theages follows Gorgias in the reconstructed reading order, the student already knows that Socrates is not serious about sending young Theages to Polus and Gorgias: he is more inclined to entertain the crippled boy's suit-of course we do not learn until Republic that Theages is crippled and that Socrates did entertain his suitthan he might otherwise appear.

On the other side, Charmides - a dialogue that begins immediately after a battle is over-harmonizes well with Gorgias (447a1), ${ }^{51}$ the beginning of which alludes to far less courageous behavior in the aftermath of war. Juxtaposed with what he will say later (Gorgias 491e6-492b1), the first words of Callicles (447a12) raise the question: "Is Callicles courageous or cowardly?" This kind of paradox is also embodied in the beautiful Charmides: Plato's young relative has every physical advantage (Charmides 154b10-c2) but-in the behind-the-scenes influence of the slippery Critias (162b10-11) - he can be seen to secretly suffer from a crippling spiritual disability. With the boy who will grow into a tyrant, Socrates discusses temperance; with a boy too frail to participate in politicsTheages has nothing but his yearning for wisdom to recommend him (Theages 121c8-d1) - Socrates openly discusses tyrants and challenges Theages to distance himself from his (childish) desire to become one of them (125e8-126a7). Demodocus and Theages are working together to persuade Socrates to take Theages as a student whereas in Gorgias, Socrates is doing his best to persuade the brilliant Callicles to become his touchstone (Gorgias 486d2-e6).

In Theages, Socrates quickly learns that (1) the boy seeks wisdom (123c9d2), (2) can easily be brought to a state of $\dot{\alpha} \pi \circ p^{\alpha} \alpha(125 \mathrm{~d} 7)$, (3) has a wide knowledge of literature (125d10-12; cf. Lamb 1927, 364 n. 1), (4) is capable of looking at himself from his father's perspective (126e8; cf. Laws 731e5-7), andmost relevant to the question of the moral impact of Socratic pedagogy-is (5)

${ }^{51}$ For another attempt to reconstruct the extra-literary aspect of Platonic pedagogy in the context of reading order, consider the question: "Who is Socrates' unnamed interlocutor in Charmides?” (cf. Lampert 2010, 235-6). This question prepares the student to identify Callicles in Gorgias (see below) and sets an example for identifying the first-order audience of Republic.

PLATO, The electronic Journal of the International Plato Society, n 11, 2011.

http://gramata.univ-paris1.fr/Plato/article103.html

(c) All rights of reproduction of any form reserved. 
speedily weaned of the temptation either to become a tyrant ruling over unwilling subjects (126a7-8; cf. Statesman 293b1) or to usurp the place of the gods (126a34; cf. Laws 818c1). In short: Theages prefers to acquire the political skill appropriate for an Athenian practicing politics in a limited and democratic context (126a9-11) and despite whatever his disqualifying physical disability may be, he is quickly proved to be the ideal student, a true lover of wisdom, and thus an appropriate interlocutor in a dialogue concerned with wisdom. In a dramatic sense, the dialogue turns on the question of whether Socrates will be able to provide Theages with the kind of political education that neither Demodocus nor the great Athenian statesmen have been able to provide for their sons, the same problem that becomes acute in Meno and is addressed, thanks to Cleitophon's question, in Republic.

Meno makes it obvious that Meno has learned his tricks from Gorgias (70b2); in other words, Meno, like Theages, follows Gorgias. And it is the connection between Meno and Gorgias (see Tetralogy VI of Thrasyllus) that suggests the rightful place of Theages: it stands between them. On the level of detective work, the reference to Themistocles, Pericles, and Cimon at Theages 126a9-10 splits the difference between Pericles, Cimon, Miltiades, and Themistocles at Gorgias 515d1 (on the one hand) and Themistocles, Aristides, Pericles, and Thucydides at Meno 93b7-94e2 (on the other) especially because the grandsons of Aristides and Thucydides are likewise to be found in Theages (130a4-e4) where Socrates tells a story about the rivalry between young Aristides and Thucydides, the sons about whom Lysimachus and Melesias are so concerned in Laches (180a6).

More importantly, Theages prepares the reader for Meno in two pedagogically significant ways. The first involves the teaching of virtue:

Well, Socrates, I have heard of the argument that you are said to put forward-that the sons of those statesmen are no better men than the sons of shoemakers; and in my opinion your words are very true, from what I am able to gather. Hence I should be an utter fool if I supposed that any of these men would impart his wisdom to me when he never was of any use to his own son, as he would have been, if he were able

PLATO, The electronic Journal of the International Plato Society, n 11, 2011.

http://gramata.univ-paris1.fr/Plato/article103.html

(c) All rights of reproduction of any form reserved. 
to be of use in this matter to anyone at all in the world.

(Theages 126d1-7)

Although there have been earlier indications of this argument in both the Protagoras (320a3-b3) and First Alcibiades (118d10-e7) -indeed this explains why "Theages" has "heard" it-the danger to Socrates of making it emerges only in the dialogue with Anytus in Meno (94e4-5). But the more important connection involves "divine dispensation."

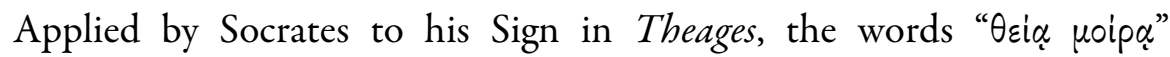
reappear in the conclusion of Meno $(99 \mathrm{e} 6,100 \mathrm{~b} 2-3)$ : Socrates famously ends that dialogue by suggesting that whatever virtue may turn out to be, it is acquired by "divine dispensation" (Meno 100b2-6). Both for those who wish to take this suggestion seriously and those who argue that recourse to $\theta \varepsilon i \alpha \mu$ roip $\alpha$ is ironic, ${ }^{52}$ Socrates' penultimate speech in the dialogue is the crucial text. ${ }^{53}$ An analysis of this speech will make the case for reading the well-known Meno in the context of reading order, preceded by Gorgias and Theages and followed by Cleitophon and Republic. For the purposes of this analysis, my own literal translation of the speech will be broken into three sections: [I] a discussion of the angry Anytus to be considered in Section \$5, [II] the qualified assertion of virtue's dependence on "a divine dispensation without mind," and [III] discussion of the hypothesisthe existence of a politician who could make another a politician-that alone would invalidate '[II].'

52 Weiss 2001 champions the ironic reading, Reuter 2001 argues for taking the suggestion seriously (see also Vlastos 1991, 125 n. 75). Between the two are Klein 1965 and Scott 1995 (also Scott 2006). These will be discussed in more detail below.

53 Meno 99e3-100a7 (Lamb): "For my part, I care not. As for him, Meno, we will converse with him some other time. At the moment, if through all this discussion our queries and statements have been correct, virtue is found to be neither natural nor taught, but is imparted to us by a divine dispensation $\left[\theta \varepsilon i \alpha \mu \mu_{1} \alpha\right.$ ] without understanding in those who receive it, unless there should be somebody among the statesmen capable of making a statesman of another. And if there should be any such, he might fairly be said to be among the living what Homer says Teiresias was among the dead- "He alone has comprehension; the rest are flitting shades." In the same way he on earth, in respect of virtue, will be a real substance among shadows."

PLATO, The electronic Journal of the International Plato Society, n 11, 2011.

http://gramata.univ-paris1.fr/Plato/article103.html

(c) All rights of reproduction of any form reserved. 
The importance of the Sign in Theages has already been indicated; along with Apology of Socrates, it is the most important source of information about its mysterious workings in Plato. In Apology, Socrates discusses the Sign in order to refute the charge that he is an atheist. In both dialogues, the Sign is called Saujoviov (Theages 128d3, Apology 30a 1 and 40a3); this leaves no doubt about its relevance to the accusations of Anytus, Meletus, and Lycon (Apology 27c8-9). In Theages, Socrates discusses the Sign in response to the attempted matchmaking of Demodocus (Theages 126c6-d1) and the keen interest in Socratic education shown by his wisdom-seeking son: only if the Sign does not interpose its veto (cf. Bailly 2003a, $106 \mathrm{n}$. 1) will Socrates be able to benefit Theages by providing him with the kind of company that will lead to the knowledge of politics the boy desires (Theages 126c3-4) ${ }^{54}$ Socrates offers a considerable amount of evidence for the Sign's efficacy (128d7-129e9) backed up by credible witnesses (128d7) and

${ }^{54}$ In Theages, Socrates tells four stories about the efficacy of the Sign on behalf of his friends, all apparently connected with its intervention and not otherwise mentioned by Plato (Bailly 2004, 54-5; Joyal 2000, 73-4 and 77-8). For two of these interventions, Socrates names witnesses (128d8 and 129a2). Two others concern military expeditions, the second involving the decision of Sannion, whose fate is yet unknown (129d4-8), the other "...in regard to the Sicilian business, many will tell you what I said about the destruction of the army" (129c8-d2; translation W.R.M. Lamb). The context suggests that the Sign alerted Socrates to the impending disaster in Syracuse on behalf of a friend but, unlike the other examples, neither friend nor witness is named, nor is the moment of the Sign's intervention described. See Joyal 1994, 29: “To accept that Socrates' prophecy about the Sicilian Expedition should be closely linked with the divine warning requires that we abandon the widely-held conception of the divine sign - to which Plato, its strongest proponent, is at considerable pains to adhere-as strictly personal and apotropaic, as distinct from prophetic." Joyal's conclusion (“Socrates' putative warning can hardly have had anything to do with his sign") ignores what it really means to "go back down into the Cave" and thus why this is the most significant passage in Theages (cf. Bailly 2004, 54). Plato compels the reader to struggle with the problem that vexes Joyal and thus to reach the only conclusion that is fully consistent with the text. As emphasized in Theages (128d4-5) the Sign primarily prevented Socrates from doing something he was about to do: in full knowledge of Alcibiades' character, we are invited to consider that Socrates intended to join the Expedition but was prevented by the Sign. We owe it to those who suffered unspeakably in the quarries of Syracuse (Thucydides 7.87) to acknowledge that our gain-Xenophon and Plato were too young to have "raced with one another as far as Aegina" (Thucydides 6.32; Jowett) but just old enough to begin appreciating Socrates, thus ensuring his literary immortality - was their grievous loss: even as but one middleaged hoplite, the battle-tested veteran of Potidaea, Amphipolis, and Delium (Apology 28e2-3) would have been unto them a tower of saving strength in their hour of need, just as he had intended to be.

PLATO, The electronic Journal of the International Plato Society, n 11, 2011.

http://gramata.univ-paris1.fr/Plato/article103.html

(c) All rights of reproduction of any form reserved. 
susceptible of empirical verification (129d2-3); most of this evidence bears directly on the relation between Socrates and those youngsters who would derive some benefit from his company, a point that will receive further attention below. But the very first thing Socrates says about the Sign that has followed him from childhood is that it is a product of "a divine dispensation" (128d2-3). It is the use

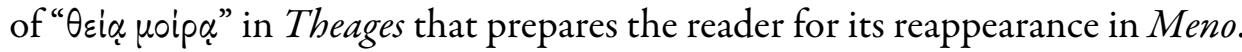

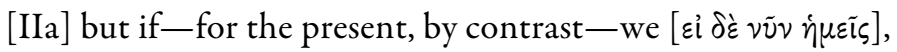

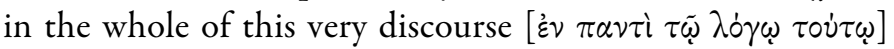
have both investigated and were speaking well [ $\kappa \alpha \lambda \tilde{\omega} \varsigma$

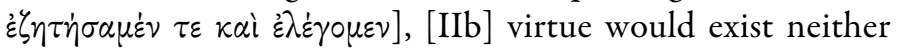
by nature nor be teachable but by a divine dispensation $[\theta \varepsilon i \alpha$.

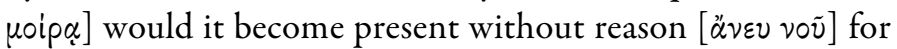
those in whom it becomes present [IIIa] unless there should exist the kind of political man who made someone else political.

It is against the conclusion presented in '[IIb]' that Roslyn Weiss's ironic reading of Meno is directed and, as this passage clearly shows, Plato provides her with several tools with which to accomplish this result. Having consigned Anytus to the future in '[I],' Socrates here returns to the present-i.e. to the entire

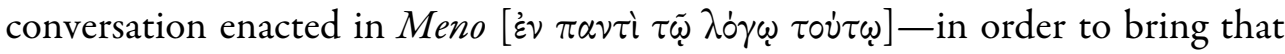
conversation to its conclusion. But to the extent that the conclusion reached in that conversation is '[IIb],' its validity is here made explicitly conditional: only if the argument that leads to '[IIb]' is valid is '[IIb]' true. This claim, of course, should surprise nobody. As it happens, Weiss-following Jacob Klein (1965, 253-4; cf. Weiss 2001, 164 n. 73) — can easily identify the flaw in that argument: the substitution of "good repute" ( $\varepsilon \dot{\delta} \delta \circ \xi i \alpha)$ for "right opinion" that occurs at Meno 99b11 (Weiss 2001, 164-7). Her fully ironic reading of '[IIb]' attributes "divine dispensation" neither to the Athenian statesmen nor to Socrates himself, who is left in possession of an eminently human means to arrive at an eminently human end..$^{5}$

55 Weiss 2001, 170: "Virtue comes not, as Meno imagines, by teaching, practice, or nature but rather "in some other way": by the hard work, the epimeleia, of moral inquiry, that is, of elenchus aimed at true opinion.” An analogous conception of the Sign can be found in Weiss 2005.

PLATO, The electronic Journal of the International Plato Society, n 11, 2011. http://gramata.univ-paris1.fr/Plato/article103.html

(c) All rights of reproduction of any form reserved. 
The problem with this reading, unlike Klein's, is that it does not leave any room for making a transition between the fraudulent Athenian statesmen-to whom the attribution of divine dispensation is clearly ironic ${ }^{56}$-and the true statesman of '[IIIa]' who can make another like himself and to whom Socrates now likens a living Teiresias:

[IIIb] Should this [sc. 'IIIa'] be the case, this one would almost be described as the kind of man among the living as Homer says Teiresias is among the dead, saying about him that "alone had he been inspired with good sense" [oinos

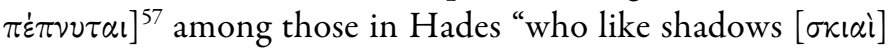
flit." [IIIc] The very same, even here [ $\kappa \alpha \grave{\varepsilon} \dot{\varepsilon} \nu \theta \dot{\alpha} \delta \varepsilon]$, such a one —as if alongside shadows [ true thing with respect to virtue.

Klein accomplishes the transference-whereby Socrates begins talking about himself instead of the fraudulent Athenian statesmen-on the basis of '[IIIa]' by citing Gorgias 521d6-8 (Klein 1965, 256 n. 47). It is here that Socrates makes the claim that he is one of a very small number who practices politics rightly: ${ }^{58}$ as a true statesman, Socrates is revealed as the one who can make another like himself. This transfer causes Klein to retroactively eliminate irony from '[IIa]' in the case of Socrates while preserving it there for the fraudulent Athenian statesmen (Klein 1965, 256). Although Klein's justification for this equivocation is unduly coy, ${ }^{59}$ the transfer itself leaves open the possibility of a reading like that of Dominic Scott, who explores the parallel between Teiresias (among the doubled "shadows" of Meno 100a5-6) and Socrates in the context of the shadowy Cave of Republic VII (Scott 1995, 48-50). Although Weiss cites the relevant passage from Gorgias and gives Scott his say in a footnote (Weiss 2001, 168 and 169 n. 86), she

${ }^{56}$ Consider Meno's assumption about the anger of Anytus (99e2; cf. Scott 1995, 43), dismissed by Socrates at '[I].'

${ }^{57}$ Autenrieth 1958, 235; cf. Meno 99d3.

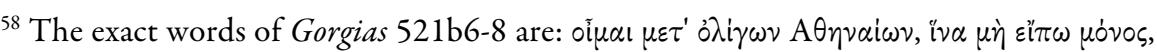

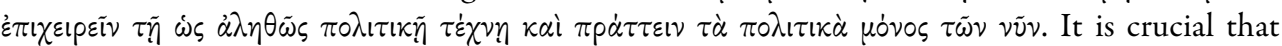
Socrates leaves open the possibility that he will not remain róvos; see below.

${ }^{59}$ Cf. Klein 1965, 256 n. 48.

PLATO, The electronic Journal of the International Plato Society, n 11, 2011. http://gramata.univ-paris1.fr/Plato/article103.html

(c) All rights of reproduction of any form reserved. 
concludes: "No such man has yet appeared; perhaps someday he will" (Weiss 2001, 169).

Scott gives a very good argument to the effect that the reader need not wait long: this "someday" will take place in Republic.

In the course of the allegory, Plato compares the cave to the underworld [Scott's note cites 521c3]; and the solitary figure of the philosopher-the only one to have had a vision of true reality-is reminiscent of Teiresias wandering among the shadows in Hades. Notice how the philosopher is even blinded when he first comes back down into the cave (516e3$17 \mathrm{a} 4$ ), and the source of his wisdom is divine (500c9). (Scott 1995, 49)

Unlike the fraudulent Athenian statesman ${ }^{60}$ both Teiresias and the philosopher who returns to the Cave lack $\varepsilon \dot{\delta} \delta \circ \xi i \alpha$ and suffer accordingly. ${ }^{61}$ But they are also endowed with $\theta \varepsilon i \alpha \mu$ oip $\alpha$ : in addition to looking forward to Republic, Scott also finds evidence for the Socrates-Teiresias connection in Meno itself where it is precisely "divine inspiration" that links them. ${ }^{62}$ After linking Socratic recollection to the blindness of Teiersias, ${ }^{63}$ Scott makes his most compelling observation:

Teiresias concealed his wisdom behind physical blindness; Socrates concealed his behind professions of ignorance and a satyr-like appearance. Furthermore, like Teiresias, he was

${ }^{60}$ Scott 2006, 186: "Socrates might be sincere in saying that they [sc. the Athenian politicians] had correct beliefs, and even virtue, but not in attributing divine dispensation to them." What they have (this is Weiss's point) is simply $\varepsilon \dot{v} \delta \circ \xi i \alpha$.

${ }^{61}$ Scott 1995, 49; cf. $361 \mathrm{~b} 8$ and 517a5-6.

${ }^{62}$ Scott 1995, 48 (emphasis mine): "Since Teiresias was a seer, divinely inspired, and blind, there is already a connection with recollection. Recollection is the divine part of us, as is made plain in the Phaedo, but also in the Meno by the religious tones in which the theory is introduced."

${ }^{63}$ Scott 1995, 48: "What is also striking is the paradox of Teiresias who, though blind, could see so much more than anyone else. Similarly, someone who recollects turns away from the sensible world and may as well be blind, yet can see (mentally) things to which the uninitiated are blind."

PLATO, The electronic Journal of the International Plato Society, n 11, 2011.

http://gramata.univ-paris1.fr/Plato/article103.html

(c) All rights of reproduction of any form reserved. 
sometimes inspired by a supernatural voice, a 'daimonion'.

(Scott 1995, 49)

Scott naturally cites Apology and not Theages for his evidence about the Sign (Scott 1995, 49 n. 25) and this is probably responsible for a certain amount of confusion about the precise extent of Socrates' sincerity (about himself) and irony (about the Athenian statesmen) in Scott's reading of Meno. ${ }^{64}$ But for the reader who comes to Meno immediately after having read Theages, the connection between Socrates and Teiresias as mediated by $\theta \varepsilon i \alpha \mu$ iा $\alpha \alpha$ is impossible to miss.

The connection between Theages and Meno suggests that the critical moment of transference-i.e. the point in the speech where Socrates leaves behind the spurious Athenian statesmen and starts talking about himselfhappens in '[IIb]' rather than '[IIIa].' In Theages, Socrates can discover no rational reason - the youth is shown to be in single-minded pursuit not only of wisdom but also of precisely that knowledge of politics to which Socrates has laid claim in Gorgias ${ }^{65}$ - why he should not be able to make Theages a politician like himself. But Socrates also knows that it would be irrational to suppose that these circumstances guarantee the project's success. ${ }^{66}$ Since education involves both student and teacher, it is hardly irrational, especially for one whose particular area of expertise is love (Theages 128b4), to implicate some third factor in the happy coincidence of their complementary aspirations. When the kind of political educator who can inspire someone else to practice politics justly-to say nothing of an effective matchmaker-acknowledges the need for a supplementary $\theta$ zi $\alpha$

${ }^{64}$ Scott 2006, 193: "It is in fact difficult to find conclusive reasons for doubting the sincerity of Socrates' reference to divine dispensation....although the conclusion [sc. 'IIb'] may be provisional, I can see no grounds for taking it as ironic." Compare Weiss 2006: "Scott refuses to recognize even the slightest irony or hyperbole in Socrates' response to Meno's challenges...”

${ }^{65}$ Compare the use of $\tau \dot{\alpha} \pi 0 \lambda ı \tau ı k \grave{\alpha}$ at Theages $126 \mathrm{c} 3$ and Gorgias $521 \mathrm{~d} 7-8$.

${ }^{66}$ Consider again the words of Socrates: “...[IIb] virtue would exist neither by nature nor be teachable but by a divine dispensation [ $\theta \varepsilon i \alpha \mu$ oip $\alpha$ ] would it become present without reason

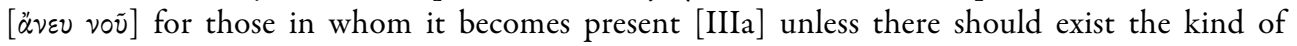
political man who made someone else political.”

PLATO, The electronic Journal of the International Plato Society, n 11, 2011.

http://gramata.univ-paris1.fr/Plato/article103.html

(c) All rights of reproduction of any form reserved. 


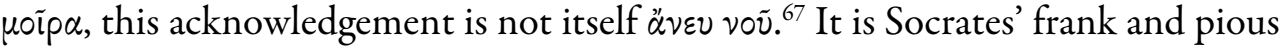
acknowledgement of his dependence on $\theta \varepsilon i \alpha \mu$ iाp $\alpha$ that proves that he, unlike the frauds who attribute their effectiveness to themselves and their "art," is not being

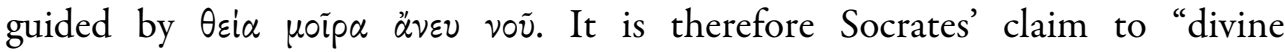
dispensation," prepared in Theages, ${ }^{68}$ that furnishes the principal basis for linking him to Teiresias in '[IIIb-c].'

There is also a serious problem with basing the transfer from ironic depiction of fraudulent Athenian statesmen to serious Socratic self-portrait in '[IIIa]' to the exclusion of '[IIb]: ${ }^{69}$ the passage at Gorgias $521 \mathrm{~d} 6-8$ says nothing about the ability of Socrates qua true statesman to make another like himself. The dramatic basis of Theages, on the other hand, ${ }^{70}$ is simply the question whether or

${ }^{67}$ Xenophon, Memorabilia 1.1.9 (Marchant): "If any man thinks that these matters are

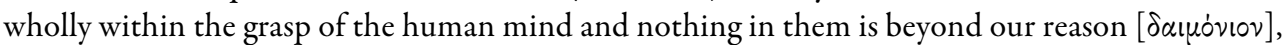

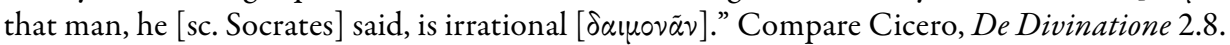

${ }^{68}$ Ion sheds some light on this problem since Socrates repeatedly uses the phrase " $\theta \varepsilon i \alpha$.

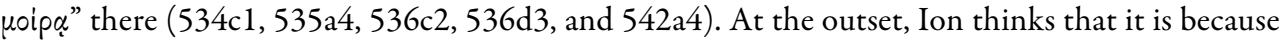
of his art (530c8; cf. 530b6) that he can express "many and fine thoughts about Homer" (530d3; translation mine): he does not see himself as operating $\alpha \nu \varepsilon v$ voṽ. Socrates attempts to persuade him that this is not the case: Ion's ability to do so depends on divine inspiration rather than art (536d2-3). But Socrates hardly makes the case for Ion's irrationality in a strictly rational manner: even if Plato leaves it to the reader to realize that the great speech of Socrates on divine inspiration $(533 \mathrm{c} 9-535 \mathrm{a} 2)$ is itself inspired (e.g. 534a7-b6), he leaves no doubt that it persuades Ion because of Socrates' personal magnetism (535a3-5) rather than the argument advanced by him there. In any case, that argument entirely depends on an account of divine inspiration that is rational only to the extent that divine inspiration actually exists (534b3). In other words, Socrates can only prove that Ion-like the Athenian politicians in Meno he resembles (cf. Meno 99d3-4 and Ion 534e5; another ligature between the two is Ion 540b3-5 and Meno 71e1-72a1) -is guided by $\theta \varepsilon i \alpha$

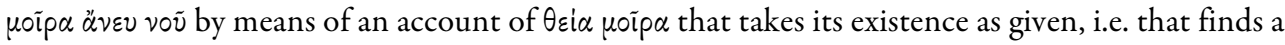
rational place for the irrational (Brickhouse and Smith 2005, 61-2). By revealing recollection in Meno (cf. Tarrant 2005), Socrates has blurred the boundary between Socrates and the divinely inspired Ion for those readers whose encounters with Ion and Diotima have not already blurred it.

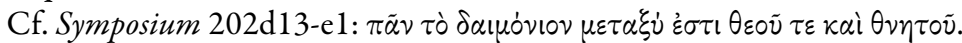

${ }^{69}$ In addition to the fact that divine dispensation (this time without the addition $\alpha \nu \varepsilon v$

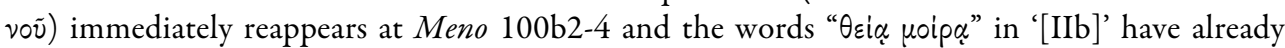
been applied in Theages to Socrates himself.

${ }^{70}$ This contrast becomes merely apparent if Socrates is serious that Callicles is a "godsend" (Gorgias 486e2-3, W.D. Woodhead translation; see following note). Consider the question posed at Nightingale 1995, 84: "But in what sense could Callicles be seen as the god's gift

PLATO, The electronic Journal of the International Plato Society, n 11, 2011.

http://gramata.univ-paris1.fr/Plato/article103.html

(c) All rights of reproduction of any form reserved. 
not Socrates will undertake the political education of Theages, an undertaking that Demodocus-echoing Socrates in Gorgias-claims has already received divine confirmation. ${ }^{71}$ Although Theages does not settle the question of whether Theages will master the political art, thereby proving Socrates to be the statesman later described in '[IIIa],' the dialogue's evident purpose is to leave precisely that question open. The point made in Theages is that it is only because of the Sign-

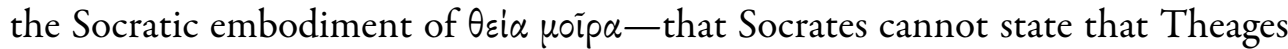
will make the progress desiderated by all three of the dialogue's interlocutors. While Theages offers no proof that Socrates will, in the specific case of Theages, function as the true statesman described in '[IIIa],' the basis of the dialogue is the assumption of both Demodocus and Theages that Socrates could do so "if he [sc. Socrates] wishes" (Theages 128c1, 128c7). Socrates, in tacit admission of his own wishes in the matter, insists - on the basis of the Sign - that this formula must be rephrased as "if it should be dear to God" (130e5-6; translation mine). In short, the reason Socrates cannot prove himself to be the kind of statesman that can create another like himself in accordance with '[IIIa]' in Theages is his rational willingness - one is tempted to cite $\mathrm{Kant}^{72}$ - to hold open a place for the extrarational (Brickhouse and Smith 2005), irrational (Woodruff 2000), non-rational (Reeve 2000), or in any case imponderable Sign, an assertion of $\theta$ ci $\alpha \mu$ oip $\alpha$ that is

to Socrates as the lyre was to Amphion?" Encountered immediately after a dialogue filled with Plato's relatives (Charmides; see Nails 2002, 244), Callicles, the principal but otherwise unknown interlocutor of Gorgias (cf. Dodds 1959, 13: "Why, then, did such a vigorous and richly endowed personality leave no mark whatever on the history of his time?"), is best understood as Aristocles son of Ariston, i.e. the pre-Socratic Plato (Dodds 1959, 14 n.1 and Bremer 2002, 100-1).

${ }^{71}$ Compare the use of Épuaıov (LSJ: "prop. gift of Hermes, i.e. unexpected piece of luck, god-

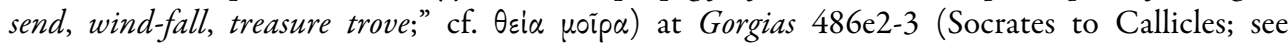
previous note) and Theages 127b2-5 (Demodocus to Socrates). Both mark the speaker's joyous anticipation of an educationally productive relationship in the offing. Earlier uses (earlier with respect to reading order) have either been ironic or in trivial (or at least non-educational) contexts: see Symposium 176c1-3 (Eryximachus, trivial context), 217a2-5 (Alcibiades, trivial context); Euthydemus 273e1-2 (Socrates, ironic), 295a6-96 (Socrates, ironic); Charmides 157c7$\mathrm{d} 1$ (Critias, probably ironic but in an educational context). Debts to "Perseus" are too seldom acknowledged; it is an हैpuaıov.

${ }^{72}$ As one also is while explaining the kind of compulsion implicit in a Longer Way reading of $\kappa \alpha \tau \alpha \beta \alpha \tau \dot{\varepsilon} \circ$; cf. Strauss 1964, 128 n. 49 and Altman 2011, 469-72.

PLATO, The electronic Journal of the International Plato Society, n 11, 2011.

http://gramata.univ-paris1.fr/Plato/article103.html

(c) All rights of reproduction of any form reserved. 
by no means, given the ways of the world and perhaps of the God that rules it (cf. $\tau \tilde{\omega} \theta \varepsilon \tilde{\omega}$ at Theages 130e6), ${ }^{73} \dot{\alpha} \nu \varepsilon v$ vov (cf. Brisson 2005, 11-12).

In conclusion, Theages supports the view that Socrates is serious in claiming that an adequate answer to Meno's opening question cannot ignore (or dismiss as ironic) the role of either $\theta \varepsilon i \alpha \mu$ oip $\alpha$ or the Sign in which he claims it is manifested despite the fact that the words " ¿బ $v \varepsilon v$ voṽ" don't apply with perfect precision to him. But a careful reading of Meno in the context of Theages suggests that the only thing being asserted with perfect precision is the necessary role of

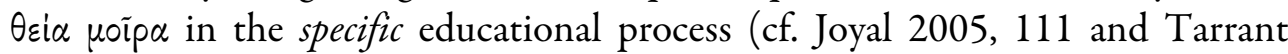
$2005,38)$ through which the true statesman - the only one who does not operate

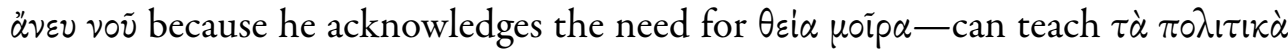
to another. Hardly surprising given its context, the parallel between Socrates and Teiresias in Meno may be said to emphasize the divine element in Socratic pedagogy, not least of all because Socrates has just demonstrated prophetic powers with respect to Anytus in '[I].' But when Socrates reappears $\pi \alpha p \dot{\alpha} \sigma \kappa i \alpha ̀ \varsigma$ in Republic (515a7, 515b9, 515c2, 516e8 and 517d9; cf. 432c8), the human element will come to the fore once again. Although the need for divine aid will hardly be concealed in Republic (Reuter 2001, 90-1), the parallel with Teiresias prepared in Meno will then help the reader to see that what Socrates is actually doing in this world $(\dot{\varepsilon} v \theta \dot{\alpha} \delta \varepsilon)$-i.e. going back down into the Cave, answering Cleitophon's question, and educating others ${ }^{74}$-fully justifies Weiss's important insight that Meno provides a vivid portrait of "virtue in the cave."

\section{Section \$4. Reading Order, Authenticity, and Platonic Hermeneutics}

${ }^{73}$ I am thus in full agreement with Reeve 2000, 36 (emphasis mine): “Socrates' theology is a mixture of rational and non-rational elements, then, but it is certainly not a covert atheology in which human reason is literally divinized." Compare Laws 818b9-c3, Pangle 1985, 137 n. 9, and Strauss 1983, 178-81.

${ }^{74}$ Note that the first exit from the Cave described by Socrates is accomplished only with the ongoing help of someone who has already left it $(515 \mathrm{c} 6-\mathrm{e} 7)$ and the fact that this unidentified tij is a paradigm instantiated by Socrates himself is particularly obvious at $515 \mathrm{~d} 5-6$. It is also worth mentioning that only a philosopher who, having left the Cave, was now helping others down below to escape it, could have created the Allegory of the Cave in the first place.

PLATO, The electronic Journal of the International Plato Society, n 11, 2011.

http://gramata.univ-paris1.fr/Plato/article103.html

(c) All rights of reproduction of any form reserved. 
It is not accidental that the Platonic dubia provide the most compelling proof for the existence of "the Reading Order of Plato's Dialogues" nor that a concern for reading order would disappear once they were athetized: the two questions hang together. The date at which a particular dialogue's authenticity was first questioned can easily be documented; the previous demise of a concern with reading order cannot be. ${ }^{75}$ Cleitophon is the best example: having been recognized as an introduction to Republic by Thrasyllus, it could only definitively lose its place in the canon once concern for reading order had already disappeared. At present, then, it is still presumed guilty but the tide is turning. My claim is that its innocence can best be proved on a new basis or rather on the basis of reviving an ancient concern for reading order ${ }^{76}$ But it is no accident that this revival follows arguments like those of Slings, Bailly, and the Straussians: an argument based on reading order must already be anchored on a prior presumption of innocence. This point is crucial: Cleitophon in particular and the Platonic dubia in general must be read as if they were genuine in order to show why they actually are so. I will call this presumption of innocence, made possible at the present time by the hard work of others, "the initial assumption." Since my purpose here is to base an authenticity argument for two representative dialogues on reading order, I regard this initial assumption as strictly hypothetical; a proof of authenticity resting on a reconstruction of the reading order of Plato's dialogues is necessarily indirect. In the classic form of indirect proof-the reductio ad absurdum - the first step is to assume the opposite of what you intend to prove. In the present case, the initial assumption is hardly the opposite of the intended conclusion and thus the argument is open to the charge of vicious circularity. Therefore the validity of the indirect proof depends on raising the following question: are there any compelling arguments for making the initial assumption?

These arguments can be divided into the a priori and a posteriori. Among the former are: (1) the historical fact that there were ancient attempts to discover the Platonic reading order, (2) every attempt to discover the synthetic unity of a

${ }^{75}$ Although Ficino had changed his mind by 1484 (Bowe 2007, 247-8), it is reasonable to suppose that those who revived Plato in the West were disposed to ignore reading order from the start. See Demetriou 2000, 135-6 on Edward Munk.

${ }^{76}$ See Altman 2010, 18-9.

PLATO, The electronic Journal of the International Plato Society, n 11, 2011.

http://gramata.univ-paris1.fr/Plato/article103.html

(c) All rights of reproduction of any form reserved. 
set of objects is vitiated by restricting at the outset the set to only some of the objects in question, (3) the $19^{\text {th }}$ century movement to reject some dialogues as spurious (most importantly by Schleiemacher) ${ }^{77}$ was inseparable from an attempt to discover a synthetic unity only in the authentic dialogues that remained (Lamm 2000), (4) efforts to organize the dialogues by "dramatic order" appear to be implicated-Zuckert's work is the exception-in a new round of setrestriction (Tejera 1999, 291-308; Nails 2002, 328; and Press 2007, 57 and 69) thereby running afoul of "(2)" no less than Schleiermacher did, and (5) since concern for reading order has some historical justification in accordance with "(1)" and would, in any case, itself constitute (if it existed) precisely such a synthetic unity, it must therefore avoid the logical trap of "(2)"-already embodied in "(3)" and soon to be resurrected in "(4)"-by starting with the initial assumption that all of the Platonic dialogues that have been preserved under Plato's name are Plato's. In other words, if it is worthwhile to entertain the reading order hypothesis, that investigation must not begin with a restricted set of dialogues.

But is there any worthwhile reason to entertain that hypothesis? In addition to the fact that Plato unquestionably wrote a series of dialogues that can easily be arranged in a chronological series (Cropsey 1995), it is implied by Zuckert's arrangement of the dialogues as a whole in accordance with dramatic chronology. The hypothesis also constitutes a plausible middle ground between the "dogmatic" and "skeptical" interpretations desiderated by those searching for a "third way" (Gonzalez 1995) in Platonic hermeneutics. Now that chronological developmentalism is no longer inevitable in the field (Howland 1991, Nails 1993, and Poster 1998), Plato studies are at a crossroads on the most basic question ("How should Plato be read?") and in the absence of any clear scholarly consensus, no plausible approach should be categorically rejected. Moreover, a modern reconstruction of the reading order of Plato's dialogues requires the careful attention to dramatic detail characteristic of the "isolationists" (Press 1993) without abandoning the pursuit of a "unitarian" end (Shorey 1903). It has also received considerable support from Christopher Rowe's Plato and the Art of Philosophical Writing (2007: 4-6, 29-31, 50-1, and 276). Finally, it is nearly

77 See Demetriou 2000, 134 on the important but often neglected role of W.G. Tennemann.

PLATO, The electronic Journal of the International Plato Society, n 11, 2011.

http://gramata.univ-paris1.fr/Plato/article103.html

(c) All rights of reproduction of any form reserved. 
equidistant from the positions of Charles H. Kahn and Charles C. Griswold Jr., two important contemporary Plato scholars who have engaged in a published debate relevant to all who are interested in Platonic hermeneutics (Griswold 1999, Kahn 2000, and Griswold 2000). Despite the fact that the reading order hypothesis has connections with both Kahn's theory of "prolepsis" (Kahn 1988, Kahn 1996; cf. Bowe 2003) and Griswold's "fictive chronology" (Griswold 1999, 387-90, Griswold 2000, 196-7; cf. Kahn 2000, 192-3), not even a faint echo of the reading order hypothesis can be heard in their debate. It deserves to be.

While the dialogue between Kahn and Griswold has begun to prepare the scholarly mainstream for the reading order hypothesis, the collaborative effort by the students of Leo Strauss (Pangle 1987), the edition of John Cooper and R.S. Hutchinson (1997), the First Alcibiades commentary of Nicholas Denyer (2001), and now many others already mentioned have been reawakening us to the fact that some or all of the dubia may well be authentic, i.e. they have been preparing that same mainstream for precisely the initial assumption that sets this particular hermeneutic circle spinning. As indicated by the publication and warm reception of Zuckert's book, the negative scholarly response to the initial assumption that all thirty-five dialogues may be genuine works of Plato and that they should be considered in terms of reading order is far less categorical today than it would have been a decade ago. But it is remarkable that these two debates-one about hermeneutics and the other about authenticity-are presently taking place at opposite ends of the field: not even Zuckert is claiming that the solution to the hermeneutic question depends on the authenticity of the dubia while, on the other hand, the reopening of the authenticity question is, for the most part, being advanced by isolationists rather than unitarians. There is therefore good reason to think that the time is ripe for reviving the hypothesis and that only an approach that doesn't depend on an initial set-restriction offers any prospect of being consistent with sound methodology. These, then, are a priori arguments for making the initial assumption.

The a posteriori argument for making the initial assumption is that once having made it, it simultaneously solves two vexing problems in Platonic studies: (1) it provides a solid but flexible framework for reaching consensus on the great hermeneutic question of "How to read a Platonic Dialogue?” (Arieti 1995) and (2) it lays to rest the authenticity question by restoring the Thrasyllan canon to

PLATO, The electronic Journal of the International Plato Society, n 11, 2011. http://gramata.univ-paris1.fr/Plato/article103.html

(c) All rights of reproduction of any form reserved. 
its pre- $19^{\text {th }}$ century form. Dialogues previously considered spurious aren't authentic simply because they have been assumed to be so: they only re-emerge as un-hypothetically genuine after they, considered in the light of the reading order hypothesis, have helped us to see the reading order of Plato's dialogues in which they, along with their greater and more beautiful sisters, all have their place. Their strictly hypothetical authenticity, i.e. the initial assumption, has functioned as "the approaches and springboards" (511b5) characteristic of Plato's dialectic and with them in place, a well-ordered universe-too elegant to be the critic's own creation-dances into view. Unlike the universe when beheld by an atheist, there can be absolutely no question about intelligent design here: Plato is in complete control of the universe created through his dialogues. What is more, Plato has repeatedly set the precedent in each one of them. In defense of an isolationist hermeneutic in which each individual dialogue is its own organic whole, Gerald Press inadvertently speaks the exact same language that should be applied to Plato's dialogues as whole:

\section{Organicism. An organic structural unity is a whole composed of many elements, structurally related in such a way that each element's doing its own part constitutes the whole's being the unity that it is. (Press 1993, 116)}

The same readers who are sensitive enough to discover these features in a single dialogue will be unable to categorically deny that Plato could have replicated this same kind of organic unity in the dialogues as a whole.

According to David Hume, the entire edifice of human knowledge depends on making a less than logically justified inductive leap. Consider the case of the mathematician David McKay, who tamed the Monster with Moonshine by asserting: " $1+196883=196884 . "$."78 $T$ There was no theoretical warrant for the view that elliptic modular functions had any connection whatsoever with the Monster Group of Finite Group Theory. But McKay decided to assume that it was no accident that the number of dimensions in the former was so very close to the second coefficient of the latter. And in practice, there was none: many more David Hume.

${ }^{78} \mathrm{I}$ am indebted to Barry Mazur for suggesting this analogy and for his insight about

PLATO, The electronic Journal of the International Plato Society, n 11, 2011.

http://gramata.univ-paris1.fr/Plato/article103.html

(c) All rights of reproduction of any form reserved. 
connections and discoveries followed. "By assuming the authenticity of the Theages, he proved that the Theages was genuine;" so will say the critics of circular reasoning. My purpose is to show that there is a higher unity-un-hypothetical in its unified pedagogical beauty and effectiveness-kick-started into visibility by a little lover's leap of reading Theages and Cleitophon as if they were Plato's. This "lover's leap" can be compared to Socrates' description of the highest, first, or dialectical portion of the Divided Line (511b3-7):

"Understand then," said I, "that by the other section of the intelligible I mean that which the reason itself lays hold of by the power of dialectics, treating its assumptions not as absolute beginnings but literally as hypotheses, underpinnings, footings, and springboards so to speak [oĩov $\dot{\varepsilon} \pi \iota \beta \dot{\alpha} \sigma \varepsilon ı \tau_{\varepsilon}$ kai $\left.\dot{\rho} p \mu \dot{\alpha} \zeta\right]$, to enable it to rise to that which requires no assumption and is the starting-point of all..."

The dialectical method I am employing is what moderns, by contrast, would call "inductive": by expanding the data-base of the dialogues-as Mendeleyev needed to pre-assume the discovery of an element or two to construct his balanced rows and columns ${ }^{79}-\mathrm{I}$ have attempted to demonstrate that "the Reading Order of Plato's Dialogues" actually exists and thus that an initial induction (e.g. that Theages and Cleitophon are authentic) leads to the discovery of a dialectical unity from which the validity of the strictly hypothetical initial assumption can then be deduced. In the playful spirit of Plato, an alternative to the reductio ad absurdum is therefore being offered here: an equally indirect inductio ad concordiam.

\section{Section \$5. From Gorgias to Republic}

The basis of Kahn's theory of proleptic composition is the claim that the "early" dialogues are best understood in relation to Republic. ${ }^{80}$ In the previous

\footnotetext{
${ }^{79}$ Strathern 2000; I am indebted to David Benedetto for suggesting this analogy.

${ }^{80} \mathrm{Kahn} \mathrm{1996,} \mathrm{48:} \mathrm{"In} \mathrm{the} \mathrm{last} \mathrm{analysis,} \mathrm{it} \mathrm{is} \mathrm{this} \mathrm{systematic} \mathrm{orientation} \mathrm{towards} \mathrm{the}$ Republic that ties all or most of these dialogues [sc. Kahn's "Group I," including Meno and Gorgias
}

PLATO, The electronic Journal of the International Plato Society, n 11, 2011. http://gramata.univ-paris1.fr/Plato/article103.html

(c) All rights of reproduction of any form reserved. 
sections, I have offered a reconstruction of a small portion of the reading order of Plato's dialogues that is likewise best understood in relation to Republic, although more specifically to the Allegory of the Cave, a reconstruction in which both Theages and Cleitophon - dismissed by Kahn-have an important place. Once we recognize that it was only the intervention of the Sign that kept Socrates from entering politics, ${ }^{81}$ his answer to Cleitophon's question becomes binding on the rest of us who can offer no such excuse. This answer is foreshadowed in Meno and, having already read Gorgias, each of us will be prepared to confront our own jury of children, just as Socrates did.

If Zuckert's theoretical ${ }^{82}$ and chronological ${ }^{83}$ justifications for placing Republic before Gorgias and Meno make less sense than Kahn's decision to do the opposite, ${ }^{84}$ her willingness to join Cleitophon to Republic and Theages to Gorgias and Meno situates my position midway between them. ${ }^{85}$ In arguing for the theoretical justification of the latter grouping, ${ }^{86}$ she makes a particularly important point:

(47)] together and offers the most enlightening perspective on their interrelationship. Such is my basic claim."

${ }^{81}$ See Zuckert 2009, 560 for an explanation of Socrates' political inactivity that ignores the Sign: "He [sc. Socrates] did not engage in public activity merely because neither he nor any other rhetorician was able to establish the necessary conditions for the rule of philosophy..." Unfortunately, rationalistic discomfort with the Sign will remain a tacit but significant cause of scholarly resistance to accepting Theages as authentic; it is a credit to Zuckert that despite being susceptible to it, she does not succumb.

${ }^{82}$ Zuckert 2009, 336-8 and 484.

${ }^{83}$ See Zuckert 2009, 302 n. 44, 336 n. 101, and 482-4 n. 2.

${ }^{84}$ On the relationship between Gorgias and Republic, see Kahn 1996, 127-8 and 142-7.

${ }^{85}$ For joining Cleitophon to Republic, see Zuckert 2009, 332-5; on Theages, see 486-91.

${ }^{86}$ Zuckert 2009, 486: "Ironically, we see in Gorgias and the Meno, Socrates angered his interlocutors and their parents more when he stopped approaching young people in the guise of a lover and instead looked more like a father figure who wished to advise and benefit them. Representatives of the family and the city began to see him as a threat rather than merely as a ridiculous character [note 7 ].”

PLATO, The electronic Journal of the International Plato Society, n 11, 2011. http://gramata.univ-paris1.fr/Plato/article103.html

(c) All rights of reproduction of any form reserved. 
In the dialogues he set at the end of the fifth century, there are, therefore, clear references to elements of the indictment, although not to the trial itself. In the Theages, Socrates explains the function of his daimonion, which he suggests in his Apology may have been responsible, in part, for the accusation that he did not believe in the gods of the city but was introducing new ones...In the Gorgias he admits that if he were dragged into court, he would not be able to defend himself, and in the Meno Plato shows how Socrates aroused the anger of his main accuser. ${ }^{87}$

She is referring, of course, to Anytus. Not only does Socrates incur the anger of Anytus in Meno, he also predicts that the two will meet again in part "[I]" of the speech, passed over in Section $\$ 3$.

The speech begins with Socrates' brief response to Meno's statement that Anytus will be angered to hear Socrates calling various Athenian statesmen "divine":

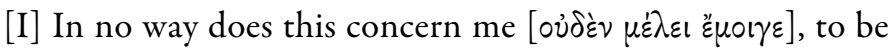
sure. With this one $[s c$. Anytus], then $[\mu \dot{\varepsilon} v]$, Meno, again at some other time we will converse [IIa] but if-for the present, by contrast...

This passage obviously points forward to the trial of Socrates and these words prove to be prophetic: there will be another discussion with Anytus. ${ }^{88}$ The presence of Anytus in Meno-in particular his threat (Meno 94e4-5) and the

${ }^{87}$ Zuckert 2009, 486 n. 7. The deleted passage reads: "In the Euthydemus, readers are reminded how and why the Athenians confused Socrates with the sophists, and in the Lysis Socrates defends himself from the charge of corrupting the young." These claims have considerably less textual basis than the ones I have quoted and probably depend on Zuckert's admittedly controversial chronological claims; cf. 482 n. 2: "Although I argue that the Theages, Euthydemus, Lysis, Gorgias, and Meno form a group, all set towards the end of the fifth century, I recognize that their dramatic dating is controversial."

${ }^{88}$ The use of $\mu \dot{\varepsilon} \lambda \varepsilon \iota$ also suggests the pun Socrates will later make on Meletus' name (Apology 26b1-2).

PLATO, The electronic Journal of the International Plato Society, n 11, 2011. http://gramata.univ-paris1.fr/Plato/article103.html

(c) All rights of reproduction of any form reserved. 
dialogue's last words ${ }^{89}$ - clearly foreshadow the events depicted in Apology. The same is true of Republic 496d2. As Zuckert points out, it also links Meno with Gorgias, where Socrates eloquently describes what his trial would be like (Gorgias 521e3-4). But neither of these dialogues gives any indication of the specific charges that will be brought against Socrates by Anytus, Meletus, and Lycon: Callicles emphasizes how unprepared Socrates will be to repel any charge (Gorgias 522c4-6) while Meno suggests that it is his blanket denigration of Athenian statesmen (Meno 94e3-4) that will get Socrates into trouble, a charge Socrates refutes in '[III]' once we recognize that Socrates of Athens is in fact the statesman par excellence as he claimed in Gorgias. In defense of that claim, Plato allows Socrates to refute the charge of rhetorical inability not only in Gorgias itself (Cicero De Oratore, 1.47) but also in Republic, here understood as Socrates' eloquent response to the extra-legal "charge" brought against him in Cleitophon. Nor is Theages without a role to play in this unfolding drama.

One of the advantages of the reading order hypothesis is that it can be used to explain why it is often appropriate to apply a passage from one dialogue to illuminate another. Applying a text from Gorgias to Meno is justified because the former precedes the latter-and does so almost immediately—in the reading order of Plato's dialogues as I have reconstructed it; it also justifies connecting Socrates to Teiresias in Meno on the basis of the Sign as described in Theages. Finally, the foreshadowing of Republic VII in Meno also makes perfect sense in light of the close proximity between the two dialogues in my reading order. If there are at present few constraints on the critic who would apply a passage from one dialogue to another, the methodological assumptions that would justify when it is appropriate to do so have likewise not been clearly articulated; this situation can be redressed by thinking in terms of reading order. Critics are already elucidating Meno on the basis of Gorgias and Republic while also drawing conclusions about it for which Theages offers the best evidence. This last point is

${ }^{89}$ In addition to the mysterious Cleitophon, two Platonic dialogues end with Socrates breaking off a conversation to attend to other matters: see Meno $100 \mathrm{~b} 7$ and Theaetetus 210d1-4. Socrates' departure in Theaetetus is motivated by the coming trial; the departure in Meno, despite some connection with the trial, seems unmotivated by comparison. The proximity of Meno and Theages might suggest the intervention of the Sign; Socrates was on the verge of continuing the conversation with Meno. As far as I know, no scholar has explained "Socrates' Silence" in Cleitophon by means of the Sign.

PLATO, The electronic Journal of the International Plato Society, n 11, 2011. http://gramata.univ-paris1.fr/Plato/article103.html

(c) All rights of reproduction of any form reserved. 
particularly true in the case of Mark Reuter (2001), whose compelling argument

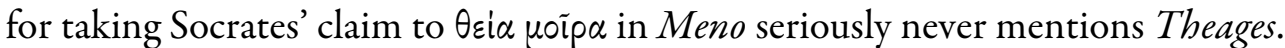
The reading order hypothesis thus justifies what many scholars are already doing. ${ }^{90}$

On the other hand, what they are already doing provides collateral evidence for the a small portion of the reading order that I have reconstructed here: an inter-connected series of five dialogues-Gorgias, Theages, Meno, Cleitophon, and Republic - that foreshadows the trial of Socrates. Cleitophon earns its rightful place in that series because it prepares the reader to understand the trial-already foreshadowed in Gorgias, Theages, and Meno-in relation to the Allegory of the Cave. But it is only in Theages that the actual charges against Socrates-that he corrupts the young and introduces new divinities (Apology 23b8-c1) - are foreshadowed and refuted. Given the centrality of corruption in Apology of Socrates, for example, the use of $\delta\llcorner\alpha \phi \theta \varepsilon i p \varepsilon i \nu$ in Theages (122a5 and $127 \mathrm{c} 2$ ) is highly significant. ${ }^{91}$

${ }^{90}$ This is particularly true when developmentalists use dramatic details to defend claims about order of composition, e.g. Dodds 1959, 23 on why Gorgias precedes Meno.

${ }^{91}$ Although the task of addressing and countering the arguments of those who deny the authenticity of Theages has been left to Bailly, there is one textual parallel bearing on the peculiar role of Socrates as thaumaturge-the conventional basis for rejecting it as genuine Plato (Guthrie 1978, 394; cf. Bailly 2004, 255) — that deserves mention because neither Bailly or Mark Joyal have noted it (Cf. Bailly 2004, 255-60; Joyal 2000, 289-90). This parallel involves the use of $\dot{\alpha} \pi \tau \dot{0} \mu \varepsilon v o s$ at Theages $130 \mathrm{e} 3$, usually taken to mean that Socrates' physical touch had magical power; even the dialogue's foremost defender has taken the word to indicate that young Aristides has been physically touched by Socrates. See Bailly 2004, 277 (emphasis mine): “A favorite teacher's glances, touches, and simple presence have extraordinary effects.” It is with Ion's ä $\pi \tau \varepsilon ı$ (Ion 535a3) - in response to Socrates' inspired speech on poetic inspiration - that this usage should be compared (535a3-5; L. Cooper): "Socrates, your words in some way touch [ä $\pi \tau \varepsilon l]$ my very soul, and it does seem to me that by dispensation from above [ $\theta \varepsilon i \alpha, \mu o i p \alpha]$ good poets convey to us these utterances of the gods." Although this indication that Socrates' "touch" is not physical may suggest a prudish reading of Theages (but see Phaedo 89b2-4), the dialogue's principal artistic felicity, particularly in juxtaposition with the erotic Charmides, is precisely Plato's creation of a deliberately titillating subtext that readers must entertain if only in order to reject: were Socrates, the master of love, conceivably interested in its physical fulfillment (Symposium 218e3-7), Demodocus as matchmaker would then be pimping his son. Is it our eventual awareness of the

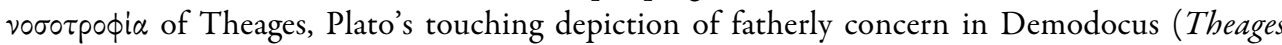
$127 \mathrm{c} 6-\mathrm{d} 5)$, or the reader's incipient awareness of Socratic piety (122b2-6) that renders this shady conception ludicrous?

PLATO, The electronic Journal of the International Plato Society, n 11, 2011.

http://gramata.univ-paris1.fr/Plato/article103.html

(c) All rights of reproduction of any form reserved. 
A few more words about placing Cleitophon between Meno and Republic are in order. To begin with, it is important to note that foremost among the "most protreptic and most beneficial" discourses to which Cleitophon refers is

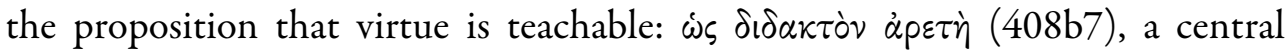
theme of Meno. More revealing is the fact that Bowe links the distinction between an aporetic and a constructive Socrates ${ }^{92}$ - upon which his reading of Cleitophon depends- to Meno:

Whereas $\dot{\alpha} \pi \circ$ pi $\alpha$ is the point at which the kinds of dialogues that Clitophon is addressing ends, it is commonly accepted that the Meno marks a turning point whereby Socrates forges beyond $\dot{\alpha} \pi \circ i^{\alpha} .^{93}$

Bowe thus offers independent confirmation for the view that a close encounter with Meno may have already enabled some students to answer: "What do you think Socrates replied to Cleitophon?" in a way that would have persuaded Plato that they were ready for Republic. And Scott goes even farther by neatly demonstrating how Plato's answer to Cleitophon's question is first broached in Meno:

Not surprisingly, anyone who adopts so critical a stance [sc. towards opinion on the basis of recollection] may be subject to the sort of treatment meted out to Teiresias, Socrates and the philosopher who returns to the cave. (Scott 1995, 50)

${ }^{92}$ Students of Gregory Vlastos will recall with affection his emphasis on Gorgias 508e6$509 \mathrm{a} 7$ as the swansong of "Socrates (E)."

${ }^{93}$ Bowe 2007, 261; the passage continues: "I agree with Charles Kahn’s contention that the explanation of $\dot{\alpha} \pi \circ p^{\prime} \alpha$ one finds in the Meno is Plato's reflection of the significance of $\dot{\alpha} \pi \circ$ pi $\alpha$ in the aporetic dialogues. I would also say that the Clitophon serves as an extended reflection on the nature of $\dot{\alpha} \pi \circ \mathrm{p} \alpha .{ }^{\prime}$ "This is yet another example of how the reading order hypothesis explains what others are already doing. Consider also 264: "The Clitophon explicitly ends in $\dot{\alpha} \pi$ opi $\alpha$ about the हैpyov of justice, but at the same time it calls us to inquire into the nature of the $\dot{\alpha} \pi \circ p^{\alpha} \alpha$ resulting from negative elenchus and exhorts us to sympathize with those who are numbed by the torpedo's shock. Read as a preface to constructive dialogues, the Clitophon is protreptic of further investigation into the nature of justice, something that is only possible once Plato has established the necessity of $\dot{\alpha} \pi \circ$ pi $\alpha$ for such an investigation, along the lines of the Meno and the Republic."

PLATO, The electronic Journal of the International Plato Society, n 11, 2011.

http://gramata.univ-paris1.fr/Plato/article103.html

(c) All rights of reproduction of any form reserved. 
In reference to Meno, this sentence reveals en passant something crucial: Socrates is the philosopher who returns to the Cave and his trial and death prove it. The parallel between Socrates and Teiresias in Meno thus foreshadows precisely the shadows of the Cave, locus of justice in Plato's Republic. This is important because it is primarily the reader's awareness that Socrates is going back down into the Cave that breaks through the Shorter Way illusion that it is only the hypothesis-based Guardians of an imaginary City, not the rest of us, who have an obligation to do so. And once this illusion is broken, it then becomes the reader's choice-as it was Cleitophon's-to take the gerundive of Book VII personally, i.e. to encounter the text dialectically by responding to it practically. No student who learns $\tau \dot{\alpha} \pi 0 \lambda \iota \tau \iota k \dot{\alpha}$ from Socrates-certainly no modern reader who experiences herself as being directly addressed by Plato at Republic VII 520b5-c1 and acts accordingly_could categorically deny the role of $\theta \varepsilon i \alpha \mu$ iip $\alpha$ in so uncanny a process. But it is a sign of Plato's peerless pedagogy that the more insistently one requires an answer to Cleitophon's question, the more readily one will find or recollect it in Republic (cf. Kahn 2006, 130) especially when one has just read Meno in the light of Gorgias and Theages.

PLATO, The electronic Journal of the International Plato Society, n 11, 2011.

http://gramata.univ-paris1.fr/Plato/article103.html

(c) All rights of reproduction of any form reserved. 


\section{WORKS CITED}

Altman, William H.F. 2007. "Leo Strauss and the Euthydemus." Classical Journal $102,355-379$.

- - . 2009a. "Altruism and the Art of Writing; Plato, Cicero, and Leo Strauss." Humanitas 22, 69-98.

- - - 2009b. "Womanly Humanism in Cicero's Tusculan Disputations." Transactions of the American Philological Association 139, 411-445.

——_. 2010a. “The Reading Order of Plato's Dialogues.” Phoenix 64, 18-51.

- - - 2010b. "Laches before Charmides: Fictive Chronology and Platonic Pedagogy," Plato: The electronic Journal of the International Plato Society 10, 1-28.

_-_. 2010c. “Catherine Zuckert's Plato’s Philosophers." Polis 27, 147-150.

- - . 2011. The German Stranger: Leo Strauss and National Socialism. Lanham.

-_- 2012. Plato the Teacher: The Crisis of the Republic. Lanham.

Annas, Julia and Christopher J. Rowe (eds.). 2003. New Perspectives on Plato, Modern and Ancient. Cambridge (U.S.).

Arieti, James A. "How to Read a Platonic Dialogue” in Gonzalez 1995.

Ausland, Hayden W. 2005. "On a Curious Platonic dialogue.” Ancient Philosophy $25,403-425$.

Autenrieth, Georg. 1958. A Homeric Dictionary. Translated by Robert P. Keep, revised by Isaac Flagg. Norman.

PLATO, The electronic Journal of the International Plato Society, n 11, 2011.

http://gramata.univ-paris1.fr/Plato/article103.html

(c) All rights of reproduction of any form reserved. 
Bailly, Jacques A. 2003a. "Review of Mark Joyal, The Platonic Theages." Gnomon $76,102-107$.

- - . 2003b. Plato's Euthyphro and Clitophon. Newburyport.

——_. 2004. The Socratic Theages. Hildesheim.

Benson, Hugh H. (ed.). 2006. A Companion to Plato. Malden.

- - - (forthcoming). Clitophon's Challenge: Platonic Dialectic \& The Philosophical Method in Plato's Classical Dialogues at http://www.ou.edu/ouphil/faculty/benson/benson.htm (accessed July 10, 2011).

Blits, Jan. 1985. "Socratic Teaching and Justice: Plato's Cleitophon." Interpretation 13, 321-334.

Bowe, G.S. 2004 "Review of Jacques A. Bailly, Plato's Euthyphro and Clitophon." $B M C R$.

——-. 2007. "In Defense of Clitophon." Classical Philology 102, 245-264.

Bremer, John. 2002. Plato and the Founding of the Academy. Lanham.

Bruell, Christopher.1999. On the Socratic Education; An Introduction to the Shorter Platonic Dialogues. Lanham.

Brickhouse, Thomas C. and Nicholas D. Smith. 2000. "Socrates' Gods and the Daimonion" in Smith and Woodruff 2000.

- - 2 2005. "Socrates' Daimonion and Rationality" in Destrée and Smith 2005.

Brisson, Luc. 2005. "Socrates and the Divine Signal according to Plato's Testimony: Philosophical Practice as Rooted in Religious Tradition” in Destrée and Smith 2005.

PLATO, The electronic Journal of the International Plato Society, n 11, 2011.

http://gramata.univ-paris1.fr/Plato/article103.html

(c) All rights of reproduction of any form reserved. 
Burnet, John. 1900-1907. Platonis Opera. Oxford.

Burnyeat, Myles. 2000. "Plato on Why Mathematics is Good for the Soul" in Timothy Smiley (ed.), Mathematics and Necessity: Essays in the History of Philosophy, 1-82. Oxford: British Academy.

Cooper, John M. (ed.) and D.S. Hutchinson. 1997. Plato, Complete Works; edited with an Introduction and Notes. Indianapolis.

Cropsey, Joseph. 1995. Plato's World: Man's Place in the Cosmos. Chicago.

Davis, Michael. 1998. “On the Intention of Plato's Cleitophon.” Metis: Revue d'anthropologie du monde grec ancien 13, 273-285.

Demetriou, Kyriacos. 1999. George Grote on Plato and Athenian Democracy: A Study in Classical Reception. Frankfurt am Main.

—_- 2000. "Reconsidering the Platonic Cleitophon." Polis 17, 133-160.

Denyer, Nicholas (ed.). 2001. Plato: Alcibiades. Cambridge (U.K.).

Destrée, Pierre and Nicholas D. Smith (eds.). 2005. Socrates' Divine Sign: Religion, Practice and Value in Socratic Philosophy. Kelowna.

Dodds, E.R. 1959. Plato, Gorgias; A Revised Text with Introduction and Commentary. Oxford.

Douglas, A.E. 1966. M. Tulli Ciceronis Brutus. Oxford.

Dunn, Michael. 1976. "Iamblichus, Thrasyllus, and the Reading order of the Platonic Dialogues." in R. Baine Harris ed., Studies in Neoplatonism: Ancient and Modern, Volume I. Albany.

Ferejohn, Michael. 2006. “Knowledge and the Forms in Plato.” In Benson 2006.

PLATO, The electronic Journal of the International Plato Society, n 11, 2011.

http://gramata.univ-paris1.fr/Plato/article103.html

(c) All rights of reproduction of any form reserved. 
Ferrari, G.R.F. (ed.). 2007. The Cambridge Companion to Plato's Republic. Cambridge (U.K.).

Gonzalez, Francisco J. (ed.). 1995. The Third Way; New Directions in Platonic Studies. Lanham.

Griswold, Charles L. Jr. 1999. "E Pluribus Unum? On the Platonic 'Corpus.” Ancient Philosophy 19, 361-97.

- - . 2000. "E Pluribus Unum? On the Platonic 'Corpus': the Discussion Continued." Ancient Philosophy 20, 195-97.

Grote, George. 1865. Plato and the Other Companions of Sokrates. London.

Grube, G.M.A. 1931. “The Cleitophon of Plato.” Classical Philology 26, 299-306.

Guthrie, W.K.C. 1969. A History of Greek Philosophy, Vol. III. Cambridge (U.K.).

——-.1975. A History of Greek Philosophy, Vol. IV. Cambridge (U.K.).

———. 1978. A History of Greek Philosophy, Vol. V. Cambridge (U.K.).

Hans, James S. 2006. Socrates and the Irrational. Charlottesville.

Heidel, W.A. 1896. Pseudo-Platonica. Baltimore.

Howland, Jacob. 1991. "Re-Reading Plato: The Problem of Platonic Chronology." Phoenix 45, 189-214.

Joyal, Mark. 1994. "Socrates and the Sicilian Expedition." L'Antiquite Classique 63, 21-33.

- - . 2000. The Platonic Theages. Stuttgart.

PLATO, The electronic Journal of the International Plato Society, n 11, 2011.

http://gramata.univ-paris1.fr/Plato/article103.html

(c) All rights of reproduction of any form reserved. 
-__. 2005. "To Daimonion and the Socratic Problem" in Destrée and Smith 2005.

Kahn, Charles H. 1988. "Plato's Charmides and the Proleptic Reading of Socratic Dialogues." Journal of Philosophy 85, 541-549.

- - - 1996. Plato and the Socratic Dialogue: The Philosophical Use of Literary Form. Cambridge (U.K.).

_-_. 2000. "Response to Griswold." Ancient Philosophy 20, 189-93.

_-_. 2006. "Plato on Recollection.” In Benson 2006.

Klein, Jacob. 1965. A Commentary on Plato's Meno. Chicago.

Kremer, Mark. 2004. Plato's Clitophon: On Socrates and the Modern Mind. Lanham.

Lamb, W.R.M. 1927. Plato: Charmides, Alcibiades I and II, etc. Cambridge (U.S.).

Lamm, Julia. 2000. “Schleiermacher as Plato Scholar.” Journal of Religion 80, 20639.

Lampert, Laurence. 2010. How Philosophy Became Socratic: A Study of Plato's Protagoras, Charmides, and Republic. Chicago: University of Chicago Press.

Lynch, John. 1997. “The Proof.” WGBH Educational Foundation. Boston.

Miller, Mitchell. 2007. “Beginning the 'Longer Way.” In Ferrari 2007.

Mishima, Teruo. 2010. "Clitophon's Challenge and the Aporia of Socratic Protreptic." Paper presented at the SAAP, Cambridge University, 21 September.

PLATO, The electronic Journal of the International Plato Society, n 11, 2011.

http://gramata.univ-paris1.fr/Plato/article103.html

(c) All rights of reproduction of any form reserved. 
Moore, Christopher. 2010. "Socrates and Clitophon in the Platonic Clitophon." Unpublished Draft of May 4, 2010 at https://webspace.utexas.edu/ crm697/www/clitophon.pdf (accessed July 10, 2011).

Nagy, P. 2003. "Proteus-shape of Platonic Studies." Review of Annas and Rowe 2003. amazon.com

Nails, Debra. 1993. "Problems with Vlastos's Platonic Developmentalism." Ancient Philosophy 13, 273-291.

- - . 2002. The People of Plato; A Prosopography of Plato and Other Socratics.

Indianapolis.

Nightingale, Andrea Wilson. 1995. Genres in Dialogue; Plato and the Construct of Philosophy. Cambridge (U.K.).

Orwin, Clifford. 1982. "The Case against Socrates: Plato's Clitophon." Canadian Journal of Political Science / Revue canadienne de science politique 15, 74153.

Pangle, Thomas L. 1985. "Socrates on the Problem of Political Science Education." Political Theory 13, 112-137.

- - - (ed.). 1987. The Roots of Platonic Political Philosophy: Ten Forgotten Socratic Dialogues, Translated, with Interpretive Essays. Ithaca.

Plax, Martin J. 2006. "Socrates' Silence in the Cleitophon and his Apology Speech." Paper presented at the Annual Meeting of the Midwest Political Science Association, April 18.

Poster, Carol. 1998. "The Idea(s) of Order of Platonic Dialogues and Their Hermeneutic Consequences.” Phoenix 52, 282-298.

Press, Gerald A. 1993. "Principles of Dramatic and Non-dogmatic Plato Interpretation" and "Introduction" to Press (ed.), Plato's Dialogues: New Studies and Interpretations. Lanham.

PLATO, The electronic Journal of the International Plato Society, n 11, 2011.

http://gramata.univ-paris1.fr/Plato/article103.html

(c) All rights of reproduction of any form reserved. 


\section{- - 2007. Plato: A Guide for the Perplexed. London.}

Raaflaub, Kurt A. 1992. "Politisches Denken und Krise der Polis: Athen im Verfassungskonflikt des späten 5. Jahrhunderts v. Chr." Historische Zeitschrift 255, 1-60.

Reeve, C.D.C. 2000. “Socrates the Apollonian?” in Smith and Woodruff 2000.

Reuter, Mark. 2001. "Is Goodness Really a Gift from God? Another Look at the Conclusion of Plato's Meno." Phoenix 55, 77-97.

Roochnik, David L. 1984. “The Riddle of the Cleitophon." Ancient Philosophy 4, 132-145.

Rowe, Christopher. 2007. Plato and the Art of Philosophical Writing. Cambridge (U.K.).

Rutherford, Richard. 1995. The Art of Plato: Ten Essays in Platonic Interpretation. London: Duckworth.

Saxonhouse, Arlene. 2005. “The Socratic Silence in Plato's Cleitophon.” Polis 22, $128-135$.

Scott, Dominic. 1995. Recollection and Experience; Plato's Theory of Learning and its Successors. Cambridge (U.K.).

- - . 2006. Plato's Meno. Cambridge (U.K.).

Sedley, David. 2007. "Philosophy, the Forms, and the Art of Ruling." In Ferrari 2007.

Shorey, Paul. 1903. The Unity of Plato's Thought. Chicago.

Slings, S.R. 1999. Plato: Clitophon. Cambridge (U.K.).

PLATO, The electronic Journal of the International Plato Society, n 11, 2011.

http://gramata.univ-paris1.fr/Plato/article103.html

(c) All rights of reproduction of any form reserved. 
-_- 2003. Platonis Rempublicam. Oxford.

Smith, Nicholas D. and Paul B. Woodruff (eds.). 2000. Reason and Religion in Socratic Philosophy. Oxford.

Souilhé, Joseph. 1930. Oeuvres Complétes de Platon, Volume 13.2. Paris.

Sprague, Rosamond Kent. 1973. Plato: Laches and Charmides; Translated with an Introduction and Notes. Indianapolis: Bobbs-Merrill.

Stahl, W.H. (ed. and trans.). 1990. Macrobius, Commentary on the Dream of Scipio. New York.

Strathern, Paul. 2000. Mendeleyev's Dream: The Quest for the Elements. New York.

Strauss, Leo. 1964. The City and Man. Chicago.

-_- 1983. Studies in Platonic Political Philosophy. Chicago.

-_- 1997. Jewish Philosophy and the Crisis of Modernity. Albany.

- - 2000. On Tyranny. Revised and expanded edition. Chicago.

Tarrant, Harold. 1993. Thrasyllan Platonism. Ithaca.

- - 2000. Plato's First Interpreters. Ithaca.

- - 2005. Recollecting Plato's Meno. London.

Tejera, Victorino. 1999. Plato's Dialogues One By One. Lanham.

Vlastos, G. 1991. Socrates, Ironist and Moral Philosopher. Ithaca.

Weiss, Roslyn. 2001. Virtue in the Cave; Moral Inquiry in the Meno. Oxford.

PLATO, The electronic Journal of the International Plato Society, n 11, 2011.

http://gramata.univ-paris1.fr/Plato/article103.html

(c) All rights of reproduction of any form reserved. 
Altman, William H.F., "Reading Order and Authenticity : The Place of Theages and Cleitophon in Platonic Pedagogy"

_-_. 2005. "For Whom the Daimonion Tolls" in Destrée and Smith 2005.

——_. 2006. "Review” of Scott 2006. Bryn Mawr Classical Review.

Woodruff, Paul. 2000. "Socrates and the Irrational" in Smith and Woodruff 2000.

Yunis, Harvey. 2007. “The Protreptic Rhetoric of the Republic" in Ferrari 2007.

Zuckert, Catherine H. 2009. Plato's Philosophers: The Coherence of the Dialogues. Chicago.

PLATO, The electronic Journal of the International Plato Society, n 11, 2011.

http://gramata.univ-paris1.fr/Plato/article103.html

(c) All rights of reproduction of any form reserved. 